\title{
PELIBATAN KOPERASI DALAM PROGRAM KUR: SEBUAH INOVASI KEBIJAKAN EKONOMI DENGAN PELUANG DAN TANTANGANNYA
}

THE INVOLVEMENT OF COOPERATIVE IN KUR PROGRAM: AN INNOVATION OF ECONOMIC POLICY WITH OPPORTUNITIES AND CHALLENGES

\author{
Latif Adam \\ Peneliti Pusat Penelitian Ekonomi, LIPI, latif_adam@yahoo.com.au
}

\begin{abstract}
Abstrak
Tulisan ini bertujuan menganalisis peluang dan tantangan pelibatan koperasi (KSP) dalam program KUR. Dengan menggunakan metode deskriptif analisis, tulisan ini menunjukkan pelibatan koperasi membuka peluang terjadinya peningkatan jangkauan KUR untuk sektor produktif dengan distribusi yang lebih merata. Namun demikian, tulisan ini juga menekankan bahwa upaya pelibatan koperasi sebagai penyalur KUR perlu dilakukan secara hati-hati. KUR merupakan produk perbankan yang terikat dengan aturan-aturan microprudentials. Koperasi memerlukan periode penyesuaian agar memahami aturan-aturan KUR. Dari perspektif kebijakan, tantangan untuk melibatkan koperasi adalah kemampuan pemerintah dalam menyederhanakan dan mempercepat mekanisme pembayaran subsidi. Pemerintah juga perlu memiliki kriteria untuk memilih mana koperasi yang kompeten dilibatkan dalam program KUR. Tulisan ini merekomendasikan kriteria untuk menyeleksi koperasi didasarkan kepada: pertama, memiliki struktur aset dan keuangan yang kuat. Kedua, memiliki pengalaman mengelola kredit mikro yang produktif. Ketiga, mampu mengembangkan SDM secara profesional dan memiliki pengetahuan mengenai kredit mikro yang produktif. Keempat, mengembangkan infrastruktur IT (Information and Technology).
\end{abstract}

Kata Kunci: KUR, Inovasi, kriteria Koperasi, UMKM, sektor produktif

Klasifikasi JEL: E51, G38, I28, O23

\begin{abstract}
This paper analyzes the opportunities and challenges for cooperatives (KSP) to participate in KUR program. By using descriptive analysis, it was found that cooperatives can play a significant role in improving the outreach of KUR on the basis of proportional sectoral and geographical distribution. However, this paper also emphasizes that efforts to invole cooperatives in the program should be implemented carefully. KUR is a banking product in which its implementation must be in line with microprudentials regulatios. Cooperatives need an adaptation period to comply with KUR's rules and regulations. Main policy challenges that need to be addressed is to simplify complex subsidy payment mechanism. The government needs also to develop selection criterias to appoint competent cooperatives to engage in the KUR program. It is recommended that participating cooperatives should meet the following criterias: First, having strong assets and capital structures. Second, having experience in managing productive microcredit loans. Third, promoting productive microcredit professional human resources. Fourth, developing IT (Information Technology) infrastructure.
\end{abstract}

Keywords: KUR, Inovation, Cooperative criteria, SMEs, productive sector

JEL Classification: E51, G38, I28, O23 


\section{PENDAHULUAN}

Pada tahun 2016, pemerintah melakukan inovasi dalam proses penyaluran KUR (Kredit Usaha Rakyat). Salah satu upaya pemerintah meningkatkan peran KUR sebagai bagian dari stimulus untuk mendorong pertumbuhan ekonomi melalui pemberdayaan UMKM (Usaha Mikro Kecil dan Menengah), adalah dengan memperluas basis lembaga keuangan penyalur KUR. Berbeda dengan pelaksanaan KUR sebelumnya, lembaga keuangan penyalur KUR tidak lagi dibatasi hanya untuk perbankan. Melalui Permenko Bidang Ekonomi No. 9/2016, pemerintah membuka peluang untuk melibatkan LKNB (Lembaga Keuangan Non-Bank), seperti koperasi, sebagai lembaga keuangan penyalur KUR.

Melibatkan koperasi sebagai penyalur KUR memunculkan peluang sekaligus tantangan dalam mendukung tata pelaksanaan KUR. Di satu sisi, sebagai sebuah lembaga yang memang secara tradisional telah cukup intens berinteraksi dan menjadi sumber permodalan yang cukup penting bagi UMKM (Usaha Mikro, Kecil, dan Menengah), pelibatan koperasi menjanjikan peluang terjadinya peningkatan penyaluran KUR secara lebih efektif dengan distribusi yang lebih merata. Artinya, koperasi memiliki potensi menjangkau UMKM baru (new comers) sebagai target utama program KUR, terutama di daerah di mana perbankan belum beroperasi secara optimal.

Namun demikian, di sisi lain, KUR pada awalnya didesain sebagai sebuah produk perbankan. Dengan demikian, KUR terikat dengan aturan-aturan microprudentials yang sangat kaku dan relatif kompleks. Seberapa jauh koperasi mampu melakukan inovasi dan beradaptasi dengan aturan-aturan microprudentials menjadi tantangan yang akan berpengaruh terhadap tata pelaksanaan KUR.

Tujuan dari tulisan ini adalah menganalisis peluang dan tantangan yang dihadapi oleh koperasi sebagai penyalur KUR. Tulisan ini juga akan menganalisis kriteria yang idealnya dijadikan persyaratan pada saat menyeleksi koperasi yang berminat menjadi penyalur KUR. Berdasarkan hasil analisis pada bagian sebelumnya, tulisan ini kemudian akan memberikan rekomendasi mengenai langkahlangkah yang perlu dilakukan pemerintah untuk mendorong partisipasi koperasi dalam program KUR.

\section{TINJAUAN PUSTAKA}

UMKM memainkan peran penting dalam perekonomian Indonesia. Pada tahun 2013, $98,8 \%$ dari 57,9 juta perusahaan yang ada di Indonesia merupakan UMKM. Mereka berkontribusi $57,6 \%$ terhadap PDB dan mampu menciptakan kesempatan kerja sebanyak 97\% (114 juta) dari total kesempatan kerja yang tersedia (Kementerian Koperasi dan UKM, 2013).

Meskipun memiliki peran penting, UMKM menghadapi sejumlah permasalahan. Mereka memiliki akses yang terbatas pada sumber permodalan (Nugroho 2011; TNP2K, 2015a; Adam dan Lestari, 2017), memiliki daerah pemasaran yang terbatas karena tidak terintegrasi dengan jaringan produksi dan pemasaran global (van Diermen, 1997; Yamamoto, 2001; IFC, 2016), kesulitan mendapatkan bahan baku dengan harga dan pasokan yang stabil (Harvie, Narjoko dan Oum, 2013; TNP2K, 2015b), dan hanya mampu mempekerjakan tenaga kerja kurang terampil (van Diermen, 1997; TNP2K, 2015b). Beragam permasalahan itu, baik secara sendiri-sendiri maupun secara bersama-sama, mempengaruhi kemampuan UMKM untuk meningkatkan produktivitasnya. Karena itu, sebagian besar studi (Yamamoto 2001; Berry, Rodriguez, dan Sandee 2001; TNP2K 2015b) menyimpulkan tingkat produktivitas yang rendah menjadi karakter yang menonjol dari UMKM di Indonesia.

Dari beragam permasalahan yang dihadapi UMKM, terbatasnya akses terhadap sumber permodalan/keuangan formal merupakan permasalahan fundamental yang paling sering disimpulkan sebagai penghambat utama UMKM untuk meningkatkan produktivitasnya. Terbatasnya akses terhadap sumber permodalan/keuangan formal menghalangi UMKM membeli lebih banyak bahan baku untuk mensiasati fluktuasi harga dan pasokan (Johnson dan Murdoch, 2007). Terbatasnya akses juga menghalangi UMKM berinvestasi di bidang teknologi terbaru yang lebih produktif dan efisien sebagai prasyarat 
untuk memperluas dan mengembangkan usaha meraka (Vos et al., 2007).

Data dan studi empiris menunjukkan kebanyakan UMKM di Indonesia memang hanya mengandalkan modal pemilik atau meminjam dari keluarga. Musa dan Priatna (1998) menemukan dari 300 UMKM yang disurvey, 75\% mengandalkan modal sendiri (self-financing) dan hanya 13\% yang meminjam dari bank. Perhitungan dari Survey Industri Mikro dan Kecil/VIMK (BPS 2014) menunjukkan persentase yang kurang lebih sama. Sekitar 83,3\% industri mikro mengandalkan modal sendiri, sedangkan untuk industri kecil proporsinya adalah $59,9 \%$. Proporsi industri mikro dan kecil yang meminjam dari bank masing-masing hanya $6,5 \%$ dan $25,6 \%$. Tanpa ada upaya untuk mendorong UMKM mengakses permodalan dari sumber keuangan formal, perkembangan dan kinerja UMKM kemungkinan akan tetap stagnan.

Terbatasnya akses UMKM terhadap sumber permodalan/keuangan formal, khususnya terhadap perbankan, bisa dijelaskan baik dari sisi permintaan maupun penawaran (Berry, Rodriguez dan Sandee, 2001; Nugroho, 2011; TNP2K, 2015a). Dari sisi permintaan, UMKM enggan mendapatkan kredit dari bank karena mereka menganggap suku bunga pinjaman bank terlalu mahal (TNP2K 2015a) atau karena mereka merasa pesimis tidak akan mampu memenuhi persyaratan kredit, seperti jaminan, rencana bisnis, dan sistem pembukuan keuangan yang sudah teraudit (Musa dan Priatna, 1998; Johnson dan Murdoch, 2007). Selain itu, banyak UMKM yang berpikiran bahwa meskipun mereka mampu memenuhi persyaratan kredit yang dibutuhkan, aplikasi mereka akan didiskriminasi dan ditolak oleh bank (Berry, Rodriguez dan Sandee, 2001; Adam, 2011; Nugroho, 2011).

Dari sisi penawaran, perbankan enggan memberikan pinjaman kepada UMKM karena beberapa permasalahan kegagalan pasar sebagai berikut. Pertama, UMKM diidentifikasi oleh perbankan sebagai pihak yang tidak berpengalaman dalam memanfatkan dan mengelola pinjaman. Mereka kebanyakan tidak memiliki pembukuan dan rencana bisnis yang jelas.
Karena itu, perbankan menghadapi kesulitan untuk menilai dan memilih mana UMKM yang layak dan tidak layak mendapatkan kredit. Dengan demikian, dari perspektif perbankan, memberikan pinjaman kepada UMKM memunculkan risiko tingginya tingkat gagal bayar (Nugroho, 2011).

Kedua, UMKM juga diidentifikasi oleh perbankan sebagai pihak yang mengajukan pinjaman dengan nominal yang relatif kecil. Karena itu, perbankan terbebani dengan tingginya biaya transaksi pada saat menseleksi UMKM yang mengajukan pinjaman, memproses pencairan pinjaman, dan mengelola serta memonitor pengumpulan pembayaran pinjaman (Johnson dan Murdoch, 2007; Vos et al. 2007; Adam, 2009).

Ketiga, proses pemberian pinjaman dari perbankan terhadap UMKM tetap terikat dengan aturan-aturan mikro-prudensial (TNP2K, 2015a). Masalahnya, sebagian besar UMKM sering tidak mampu memenuhi persyaratan-persyaratan mikro-prudensial, seperti jaminan, memiliki surat ijin usaha secara formal, dan memiliki pembukuan keuangan serta rencana bisnis yang jelas (Harvie, Narjoko dan Oum, 2013; TNP2K, 2015a). Akibatnya, perbankan lebih memilih menyalurkan pinjaman ke UMKM formal dan memiliki agunan yang jumlahnya masih relatif sedikit.

Pemerintah Indonesia sudah sejak lama berupaya memperbaiki kegagalan di pasar keuangan/kredit agar akses UMKM terhadap sumber permodalan semakin terbuka. Salah satu upaya dari pemerintah adalah memperkenalkan kembali dan merevitalisasi keuangan mikro pada tahun 1960-an. Keuangan mikro telah menjadi bagian penting dari sejarah ekonomi Indonesia, jauh sebelum kemerdekaan negara ini di tahun 1945 (Thee, 2006). Memang, sebagaimana ditunjukkan Hamada (2010), Lembaga Keuangan Mikro (LKM) dan layanan keuangan berskala kecil telah populer bagi banyak orang Indonesia selama satu abad, terutama bagi mereka yang tinggal di Jawa.

Bank Rakyat Indonesia (BRI) adalah salah satu LKM terbesar di dunia dan menjadi LKM pertama yang menyediakan kredit mikro bagi UMKM pada awal 1960-an. Selama Pemerintahan Orde Baru, BRI berfungsi 
sebagai bank yang menyalurkan kredit dengan suku bunga yang disubsidi pemerintah melalui program kredit mikro untuk pertanian kepada petani kecil, yaitu BIMAS (Bimbingan Masal). BIMAS dirancang sebagai bagian dari program intensifikasi padi yang bertujuan mencapai swasembada beras (Hamada, 2010; Hadiwinata, 2003; McLeod, 1994). Untuk menjalankan BIMAS, BRI melengkapi diri dengan layanan unit desa (BRI Unit Desa). Sayangnya, program ini kurang begitu sukses, karena tingginya tingkat gagal bayar, mencapai lebih dari 60\% pada tahun 1981 .

Paling tidak terdapat tiga alasan mengapa program BIMAS kurang begitu berhasil (McLeod, 1994; Hadiwinata, 2003; Siebel, 2005). Pertama, karyawan BRI tidak secara murni memandang BIMAS sebagai produk perbankan. Dengan demikian, proses seleksi dan pemantauan nasabah tidak didasarkan kepada prinsip-prinsip penyaluran kredit secara mikro-prudensial. Akibatnya, sebagian besar petani yang terseleksi sebagai nasabah BIMAS memiliki kapasitas yang rendah untuk mengembalikan dan melunasi pinjaman tepat jumlah dan tepat waktu.

Kedua, BIMAS diimplementasikan dengan skema tidak ada insentif bagi petani yang mampu mengembalikan pinjaman. Demikian juga, tidak ada skema hukuman bagi petani yang gagal mengembalikan pinjaman. Dalam program BIMAS, tidak ada kejelasan siapa yang menanggung seluruh risiko jika nasabah gagal mengembalikan pinjaman tepat waktu dan tepat jumlah. Dengan skema seperti ini, moral hazard berkembang secara subur dimana nasabah secara sengaja menunda pembayaran pinjaman.

Ketiga, sebagian Koperasi Unit Desa (KUD) memiliki kapasitas dan profesionalitas yang rendah sebagai lembaga perantara penyalur BIMAS. Bekerja sama dengan pejabat pemerintah, KUD sering memanipulasi laporan keuangan, yang pada gilirannya membuka ruang bagi nasabah untuk menunda atau tidak mengembalikan pinjaman sama sekali.

Setelah era BIMAS berakhir, pada tahun 1970-an pemerintah melanjutkan penyediaan beragam program kredit mikro untuk UMKM melalui perbankan dengan tetap menggunakan skema subsidi suku bunga. Beberapa diantaranya adalah Kredit Investasi Kecil (KIK); Kredit Modal Kerja Permanen (KMKP); Kredit Usaha Kecil (KUK); Kredit Ketahanan Pangan dan Energi (KKPE); dan Kredit Usaha Tani (KUT). Semua program kredit mikro itu ditujukan untuk membantu kebutuhan permodalan UMKM untuk berbagai tujuan, seperti modal kerja, investasi, dan membantu petani kecil. Namun demikian, tidak ada satupun dari program ini yang berlanjut (sustain) karena alasan yang hampir sama dengan BIMAS (Thee, 2006).

Penyediaan beragam program kredit mikro dengan skema subsidi suku bunga mengindikasikan bahwa pemerintah memiliki komitmen yang kuat dalam pengembangan UMKM. Sayangnya, pemerintah tidak pernah melakukan evaluasi secara komprehensif mengenai efektivitas program-program kredit mikro dalam mendorong pengembangan UMKM (Hill, 2002). Namun demikian, beberapa studi empiris (Musa dan Priatna, 1998; Sato, 2000; Firdausy, 2005; Adam, 2009) menyimpulkan bahwa sebagian besar program kredit mikro tidak efektif dalam mendorong pengembangan dan kinerja UMKM. UMKM yang menikmati dan tidak menikmati program keuangan mikro memiliki pola perkembangan yang serupa, menunjukkan bahwa peran program keuangan mikro dalam membantu pengembangan UMKM masih dipertanyakan efektivitasnya (Musa dan Priatna, 1998; Thee, 2003; Adam, 2009).

Pola utilisasi dan tingkat partisipasi mengurangi efektivitas program kredit mikro dalam mendorong perkembangan UMKM. Johnson dan Murdoch (2007) serta Takashi, Higashikita dan Tsukada (2010) menunjukkan kebanyakan UKM menggunakan kredit mikro secara tidak produktif, bukan untuk memperluas dan mengembangkan usaha, tetapi untuk kebutuhan konsumtif, seperti membayar biaya sekolah, perawatan medis, dan renovasi rumah. Selain itu, meskipun beberapa program kredit mikro telah berjalan relatif lama, program-program itu kurang begitu efektif menjangkau UMKM (Firdausy 2005). Tingkat partisipasi untuk programprogram kredit mikro bersubsidi suku 
bunga selalu rendah, kurang dari 20 persen (Firdausy, 2005; Hamada, 2010).

Rendahnya tingkat partisipasi menunjukkan bahwa sebagian besar UMKM belum bisa mengakses program-program kredit mikro bersubsidi. Penyebabnya menurut P2E-LIPI (2014) serta Adam dan Lestari (2017) karena bank pelaksana masih mensyaratkan agunan kepada UMKM yang mengajukan usulan untuk mendapatkan kredit mikro bersubsidi, paling tidak untuk dua alasan. Pertama, sebagai instrumen untuk menciptakan titik keseimbangan diantara pasokan (supply) kredit yang terbatas dengan permintaan kredit yang relatif tinggi. Kedua, sebagai metode untuk menseleksi UMKM yang diasumsikan memiliki risiko gagal bayar rendah.

Berdasarkan berbagai kelemahan yang teridentifikasi dari program-program kredit mikro sebelumnya, pada tahun 2007 Pemerintah Indonesia mengubah pendekatan untuk mengintervensi pasar kredit mikro, dari model subsidi ke kredit komersial, dengan memperkenalkan Kredit Usaha Rakyat (KUR). Dalam kaitan ini kredit komersial didefinisikan sebagai praktek pelaksanaan kredit mikro berdasarkan prinsip-prinsip pasar dalam kerangka aturan lembaga keuangan/ perbankan (Hamada, 2010). Memang, dalam desain program KUR, teknis pelaksanaan program ini diputuskan oleh bank/lembaga keuangan pelaksana berdasarkan prinsipprinsip mikro-prudensial. Pemerintah hanya menyediakan skema penjaminan parsial (2007 - 2014) atau mensubsidi sebagian suku bunga (2015 - sekarang) dan menentukan prinsip-prinsip umum KUR, seperti plafon kredit dan batas atas suku bunga.

\section{METODOLOGI}

Metode yang digunakan tulisan ini adalah analisis deskriptif. Penggunaan metode analisis deskriptif memungkinkan penulis menggambarkan secara sistematis, faktual, dan akurat mengenai tantangan dan peluang koperasi sebagai penyalur KUR. Penggunaan metode analisis ini juga membuka peluang bagi penulis untuk mengidentifikasi variasi permasalahan, melakukan hubungan antar variabel KUR (aturan, ketentuan, dan proses implementasi penyaluran KUR selama ini) dengan kapasitas dan bisnis proses yang selama ini berjalan di koperasi (keuangan, tata kelola, infrastruktur, dan sumber daya manusia), dan melakukan generalisasi dari temuan-temuan yang memiliki validitas universal.

Meskipun metode analisis deskriptif memungkinkan untuk melihat hubungan diantara berbagai variabel, seberapa kuat dan signifikan hubungan diantara berbagai variabel itu sulit diukur secara statistik. Selain itu, metode analisis deskriptif sulit untuk direplikasi dan diverifikasi ulang karena sifatnya yang observasional, kontekstual, dan mengandalkan pendapat serta informasi dari pihak dan sumber yang menjadi objek penelitian.

Terlepas dari kelemahannya, metode analisis deskriptif tetap relevan digunakan untuk menjawab tujuan dari tulisan ini. Untuk mendukung metode deskriptif, tulisan ini menggunakan teknik analisis komparasi. Teknik komparasi memungkinkan penulis tidak saja membandingkan aturan dan ketentuan KUR dengan kapasitas dan bisnis proses koperasi, tetapi juga membandingkan kapasitas dan bisnis koperasi yang satu dengan yang lainnya.

Selain menggunakan data sekunder yang diambil dari Komite Kebijakan KUR (Realisasi Penyaluran KUR), Kementerian Keuangan (SIKP), Bank Indonesia/OJK (SID), Kementerian Koperasi dan UKM (data mengenai Koperasi dan UMKM), dan BPS (SUSENAS dan VIMK), analisis komparasi dalam tulisan ini juga menggunakan data dan informasi dari kunjungan lapangan ke lima koperasi sebagai berikut. Pertama, koperasi yang telah mengajukan usulan dan mendapatkan ijin sebagai penyalur KUR, yaitu Kospin Jasa (Pekalongan-Jawa Tengah) dan Obor Mas (Maumere-Nusa Tenggara Timur). Kedua, koperasi yang telah mengajukan usulan tetapi belum mendapatkan ijin sebagai penyalur KUR, yaitu Balo' Toraja (Tana Toraja-Sulawesi Selatan) dan Keling Kumang (Sintang-Kalimantan Barat). Ketiga, koperasi yang memiliki potensi, tetapi belum mengajukan usulan untuk menjadi penyalur KUR, yaitu Pancur Kasih (PontianakKalimantan Barat) 


\section{Analisis Pelaksanaan KUR}

KUR merupakan program untuk meningkatkan akses UMKM terhadap sumber permodalan, khususnya kredit perbankan. Secara konseptual, UMKM yang menjadi target program KUR adalah mereka yang berusaha di sektor produktif dan telah menjalankan usahanya secara feasible, tetapi masih unbankable (tidak memiliki persyaratan-persyaratan untuk mengakses kredit perbankan, utamanya collateral). Desain program KUR menegaskan peningkatan akses UMKM terhadap sumber permodalan diharapkan mampu mendorong kinerja UMKM, sehingga UMKM pada gilirannya akan lebih mampu menjalankan perannya secara optimal sebagai tempat penciptaan lapangan kerja dan pendapatan masyarakat, khususnya masyarakat dengan status sosial-ekonomi menengah ke bawah (TNP2K, 2014; Kemenko Bidang Ekonomi, 2017).

Adam dan Lestari (2017) menunjukkan, pelaksanaan KUR menarik jutaan UMKM untuk memanfaatkannya. Lebih dari itu, beberapa hasil penelitian (P2E LIPI, 2014; TNP2K, 2014) menyimpulkan KUR berdampak positif terhadap pemberdayaan UMKM. Misalnya, dengan membandingkan kinerja UMKM penerima dan bukan penerima KUR, P2E LIPI (2014) menunjukkan kinerja UMKM penerima relatif lebih baik dibandingkan dengan kinerja UMKM bukan penerima dilihat dari tingkat keuntungan, pendapatan dan pemilikan aset. Sejalan dengan itu, penelitian TNP2K (2014) di 19 provinsi menunjukkan setelah mendapatkan KUR, proporsi terbesar dari 232 UMKM penerima KUR yang disalurkan melalui BRI, BSM, dan BPD mampu meningkatkan penciptaan kesempatan kerja dan kepemilikan aset bisnis.

Tingginya minat UMKM untuk memanfaatkan KUR dan terdapatnya indikasi bahwa KUR mampu mendorong kinerja UMKM memotivasi Pemerintahan Jokowi-JK untuk mempertahankan program ini. Karena itu, setelah pelaksanaan KUR Tahap Pertama (Nopember 2007 - Desember 2014) berakhir, sejak Agustus 2015 sampai sekarang, Pemerintahan Jokowi-JK kemudian mengimplementasikan KUR Tahap Kedua dengan melakukan beberapa perubahan pada tataran baik filosofis maupun praktis pelaksanaanya (Tabel 1). Misalnya, meskipun program KUR tetap dipertahankan sebagai instrumen pemberdayaan UMKM, tetapi fokusnya mengalami perubahan yang cukup substansial. KUR Tahap Pertama menjadi bagian dari program percepatan penanggulangan kemiskinan. Sementara KUR Tahap Kedua lebih diarahkan sebagai stimulus untuk mendorong pertumbuhan ekonomi yang sedang mengalami perlambatan.

Selain itu, pemerintah tidak lagi menyediakan subsidi penjaminan seperti yang selama ini menjadi karakter utama KUR Tahap Pertama. Sebagai penggantinya, pada KUR Tahap Kedua pemerintah menyediakan subsidi suku bunga. Melalui perubahan skema subsidi, pemerintah berharap program KUR mampu meningkatkan daya jangkaunya (outreach), khususnya untuk usaha mikro dan kecil (UMK). Asumsi pemerintah adalah, subsidi suku bunga akan menurunkan suku bunga KUR sehingga nasabah baru dari kelompok UMK akan terstimulasi untuk mengakses program ini. Terkait dengan penjaminan, meskipun hal ini tetap dipertahankan, prosesnya lebih ditentukan melalui mekanisme business to bussines antara bank pelaksana dengan perusahaan penjaminan.

Manajemen pengelolaan basis data nasabah (debitur) dan calon nasabah pada KUR Tahap Kedua juga dilakukan secara on line untuk meningkatkan transparansi dan akuntabilitas penyaluran KUR melalui pemberlakuan SIKP (Sistem Informasi Kredit Program). SIKP adalah pangkalan data calon debitur KUR yang bisa di entry tidak hanya oleh bank pelaksana, tetapi juga oleh kementerian teknis, pemerintah daerah, dan perusahaan penjaminan. Setiap identitas debitur KUR harus tercatat sebagai calon debitur di SIKP. Jika tidak, pemerintah berhak untuk tidak membayar subsidi bunga terhadap debitur KUR itu.

Pemberlakuan SIKP membuat sistem transaksi KUR di setiap lembaga keuangan pelaksana harus terkoneksi dengan pangkalan SIKP. Bagi lembaga keuangan penyalur, implikasinya adalah mereka harus membangun dan mengembangkan jaringan 
Tabel 1. Perbedaan dan Persamaan KUR Periode 2007-2014 dengan KUR Periode 2015-2016

\begin{tabular}{|c|c|c|c|}
\hline & KUR 2007-2014 & KUR 2015 & KUR 2016 \\
\hline Skema dan tarif & Penjaminan: IJP 3,25\% & $\begin{array}{l}\text { Subsidi bunga: } 7 \% \\
\text { (Mikro), 3\% (Ritel), } \\
12 \% \text { (TKI) }\end{array}$ & $\begin{array}{l}\text { Subsidi bunga: } \\
10 \% \text { (Mikro), 5,5\% } \\
\text { (Ritel), } 12 \% \text { (TKI) }\end{array}$ \\
\hline Bunga end-user & - KUR Mikro maximum $22 \% /$ pa efektif & $\begin{array}{l}\text { KUR Mikro dan Ritel } \\
\text { maximum } 12 \% / \text { pa } \\
\text { efektif }\end{array}$ & $\begin{array}{l}\text { KUR Mikro dan } \\
\text { Ritel maximum } \\
9 \% / \text { pa efektif }\end{array}$ \\
\hline Plafon dan tenor & 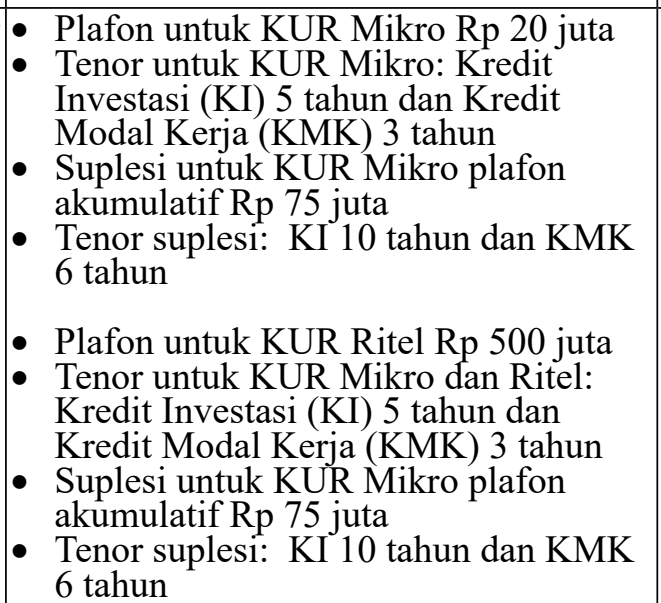 & \multicolumn{2}{|c|}{$\begin{array}{l}\text { - Plafon untuk KUR Mikro Rp } 25 \text { juta } \\
\text { - Tenor untuk KUR Mikro: Kredit } \\
\text { Investasi (KI) } 5 \text { tahun dan Kredit } \\
\text { Modal Kerja (KMK) } 3 \text { tahun } \\
\text { - Suplesi untuk KUR Mikro plafon } \\
\text { - Tenumulatif Rp } 75 \text { juta } \\
\text { tenor suplesi: KI } 7 \text { tahun dan KMK } 4 \\
\text { - Plafon untuk KUR Ritel Rp } 500 \text { juta } \\
\text { - Tenor untuk KUR Ritel: Kredit } \\
\text { Investasi (KI) } 5 \text { tahun dan Kredit } \\
\text { - Modal Kerja (KMK) } 4 \text { tahun } \\
\text { - Tuplesi untuk KUR Ritel plafon } \\
\text { akumulatif Rp 500 juta } \\
\text { tahor suplesi: KI } 7 \text { tahun dan KMK } 5\end{array}$} \\
\hline Agunan & $\begin{array}{l}\text { - Agunan pokok: kegiatan usaha } \\
\text { - Agunan tambahan tidak ada }\end{array}$ & \multicolumn{2}{|c|}{$\begin{array}{l}\text { - Agunan pokok: kegiatan usaha } \\
\text { - Agunan tambahan: sesuai penilaian } \\
\text { bank, tanpa perikatan }\end{array}$} \\
\hline Target group & $\begin{array}{l}\text { Usaha produktif, layak, namun belum } \\
\text { bankable }\end{array}$ & \multicolumn{2}{|c|}{$\begin{array}{l}\text { Usaha mikro produktif, layak dan belum } \\
\text { memenuhi persyaratan agunan }\end{array}$} \\
\hline $\begin{array}{l}\text { Cakupan } \\
\text { penjaminan }\end{array}$ & $\begin{array}{l}\text { - Sektor prioritas (pertanian, perikanan, } \\
\text { industri kecil dan TKI) mendapat } \\
\text { jaminan sampai dengan } 80 \% \\
\text { - Sektor non-prioritas mendapat jaminan } \\
\text { sampai dengan } 70 \%\end{array}$ & \multicolumn{2}{|c|}{$\begin{array}{l}\text { Kesepakatan diantara Bank pelaksana } \\
\text { dengan perusahaan penjaminan }\end{array}$} \\
\hline Sektor & Mikro seluruh sektor & \multicolumn{2}{|c|}{$\begin{array}{l}\text { Mikro di sektor pertanian, perikanan, } \\
\text { industri pengolahan dan perdagangan } \\
\text { terkait }\end{array}$} \\
\hline $\begin{array}{l}\text { Basis data dan } \\
\text { online system }\end{array}$ & $\begin{array}{l}\text { Basis data dan online system belum } \\
\text { terbangun }\end{array}$ & \multicolumn{2}{|c|}{$\begin{array}{l}\text { - Pengembangan SIKP secara bertahap } \\
\text { dengan server di Kemenkeu } \\
\text { - Bank wajib membangun online system }\end{array}$} \\
\hline Pengecekan SID & KUR Mikro tidak perlu cek SID & \multicolumn{2}{|c|}{ KUR Mikro perlu cek SID } \\
\hline $\begin{array}{l}\text { Lembaga } \\
\text { Keuangan } \\
\text { Pelaksana }\end{array}$ & Bank Umum dan BPD & \multicolumn{2}{|c|}{ Bank Umum, BPD, dan LKNB } \\
\hline
\end{tabular}

Sumber: Kemenko Bidang Ekonomi (2017)

IT (Information Technology) yang bisa terhubung secara langsung dengan jaringan SIKP. Kesiapan jaringan IT ini menjadi keharusan bagi setiap lembaga keuangan yang ingin berpartisipasi sebagai penyalur KUR.

Pada dua tahun pertama sejak KUR tahap kedua mulai diimplementasikan, realisasi penyaluran KUR selalu lebih rendah dibandingkan dengan target yang ditetapkan. Ini berbeda dengan kondisi yang terjadi pada periode implementasi KUR tahap pertama (2007-2014), dimana realisasi penyaluran KUR selalu lebih tinggi dibandingkan dengan targetnya (Gambar 1.). Ketidakberhasilan realisasi penyaluran KUR Tahap Kedua mencapai target yang ditetapkan merupakan implikasi dari rendahnya realisasi penyaluran KUR Mikro. Misalnya, pada tahun 2015 realisasi penyaluran KUR Mikro hanya mencapai 74,2 persen dari target yang ditetapkan (Rp 20 triliun). Sementara itu, realisasi penyaluran KUR Retail justru melebihi target, mencapai angka 108 persen dari target yang ditetapkan ( $\mathrm{Rp} 9$ triliun).

Pola pencapaian dua tipe KUR yang berbeda mengimplikasikan bahwa bagi 


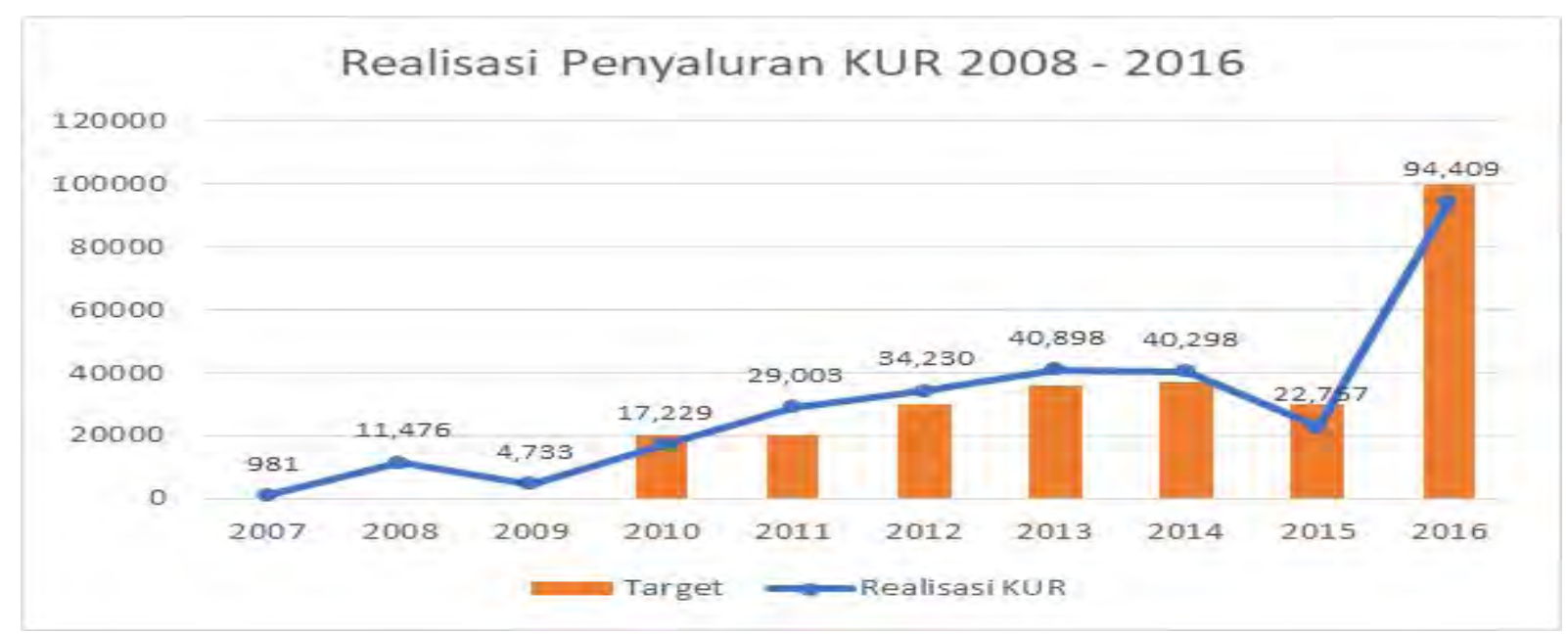

Gambar 1. Target dan Realisasi Penyaluran KUR, 2008-2016

Sumber: Kemenko Bidang Ekonomi (Berbagai tahun, diolah)

lembaga keuangan pelaksana, menyalurkan KUR Mikro relatif lebih sulit dibandingkan dengan menyalurkan KUR Ritel. Masalah ini penting menjadi perhatian karena target penyaluran KUR tahap kedua, khususnya untuk KUR Mikro, selalu naik secara signifikan meskipun pada tahun sebelumnya lembaga keuangan pelaksana tidak berhasil menyalurkan KUR sesuai target yang ditetapkan.

Paling tidak terdapat dua faktor yang membuat lembaga keuangan pelaksana menghadapi kesulitan mencapai target penyaluran KUR Mikro. Pertama, permintaan untuk mendapatkan KUR Mikro kebanyakan berasal dari UMK. Masalahnya adalah lembaga keuangan mengalami kesulitan menyeleksi UMK yang benar-benar feasible dan mampu memenuhi persyaratan kredit (bankable). Kedua, nominal kredit yang diajukan UMK untuk mendapatkan KUR Mikro jauh lebih kecil dibandingkan dengan batas atas kredit (Rp 25 juta). Karena itu, biaya transaksi untuk menyalurkan KUR Mikro relatif lebih mahal dibandingkan dengan biaya transaksi untuk menyalurkan KUR Ritel.

Fakta bahwa lembaga keuangan pelaksana kurang berhasil mencapai peningkatan target penyaluran KUR yang telah ditetapkan mendorong pemerintah untuk berinovasi dengan memperluas keterlibatan lembaga keuangan penyalur. Berbeda dengan periode 2007-2014, lembaga keuangan penyalur KUR tidak dibatasi hanya untuk bank umum nasional, khususnya bank milik pemerintah, dan BPD saja. Sejak tahun 2016, pemerintah mulai melibatkan LKNB (lembaga keuangan non-bank), khususnya beberapa perusahaan leasing, seperti BCA Finance, Adira Finance, Federal International Finance, Mega Central Finance. Pada Tahun 2017, melalui Permenko Bidang Ekonomi No. 9/2016, pemerintah mendorong KSP (Koperasi Simpan Pinjam) dan KSPS (Koperasi Simpan Pinjam Syariah) untuk terlibat sebagai penyalur KUR.

Terlepas dari pelibatan LKNB, meskipun tidak mencapai target, dilihat dari beberapa indikator, seperti rata-rata jumlah nasabah per bulan ataupun rata-rata pinjaman per nasabah, KUR Tahap Kedua sebenarnya lebih ekspansif dibandingkan dengan KUR Tahap Pertama. Secara rata-rata, KUR 2015 dan KUR 2016 tersalur masing-masing untuk 222.972 orang dan 365.550 orang per bulan, lebih tinggi dibandingkan dengan KUR 20072014 yang tersalur untuk 145.248 orang per bulan. Rata-rata kredit per nasabah pada KUR 2015 dan 2016 juga lebih tinggi dibandingkan dengan rata-rata kredit per nasabah pada KUR 2007-2014 (Tabel 2).

Dalam kaitan dengan kenaikan rata-rata jumlah nasabah per bulan, kemungkinannya karena suku bunga (cost of fund) yang lebih rendah menurunkan risiko pinjaman sehingga menarik minat nasabah baru untuk mengakses KUR. Sementara itu, dalam kaitan dengan kenaikan rata-rata kredit per nasabah, faktor penyebabnya kemungkinan adalah: pertama, bank pelaksana memberikan suplesi terhadap 
Tabel 2. Rata-Rata Nasabah dan Rata-Rata Pinjaman per Nasabah per Bulan

\begin{tabular}{|c|c|c|c|c|}
\hline & $\begin{array}{c}2007-2014 \\
\text { (November } 2007 \\
\text {-November 2014) } \\
\end{array}$ & $\begin{array}{c}2015 \\
\text { (14 Agustus - } \\
\text { 31 Desember) }\end{array}$ & $\begin{array}{c}2016 \\
\text { (1 Januari - } 31 \\
\text { Desember) }\end{array}$ & $\begin{array}{c}2017 \\
\text { (1 Januari - } \\
\text { 30 Juni) }\end{array}$ \\
\hline $\begin{array}{l}\text { KUR Mikro: } \\
\text { Nasabah (orang) } \\
\text { Penyaluran (Rp Juta) }\end{array}$ & $\begin{array}{c}11.326 .246 \\
8,4\end{array}$ & $\begin{array}{c}944.109 \\
14,93\end{array}$ & $\begin{array}{l}4.140 .008 \\
15,83\end{array}$ & $\begin{array}{c}1.920 .895 \\
16,72\end{array}$ \\
\hline $\begin{array}{l}\text { KUR Retail: } \\
\text { Nasabah (orang) } \\
\text { Penyaluran (Rp Juta) }\end{array}$ & $\begin{array}{c}1.019 .811 \\
78,6\end{array}$ & $\begin{array}{l}59.263 \\
146,07\end{array}$ & $\begin{array}{c}206.361 \\
138,57\end{array}$ & $\begin{array}{l}96.010 \\
134,47\end{array}$ \\
\hline Total Nasabah & 12.346 .057 & 1.003 .372 & $\begin{array}{c}4.357 .873 \\
\text { (Termasuk KUR TKI } \\
12.157 \text { nasabah) }\end{array}$ & 2.025 .009 \\
\hline $\begin{array}{l}\text { Rerata nasabah per } \\
\text { bulan }\end{array}$ & 145.248 & 222.972 & 396.170 & 337.501 \\
\hline Tingkat NPL (\%) & 3,3 & 0 & 0,37 & 0,002 \\
\hline
\end{tabular}

Sumber: Kemenko Bidang Ekonomi (Berbagai tahun, diolah)

Keterangan: Pada tahun 2015, NPL diasumsikan 0\% karena pelaksanaannya baru dimulai pada Bulan Agustus, sedangkan kredit bermasalah didefinisikan jika seorang nasabah tidak mampu membayar cicilan dan bunga kredit ke bank selama 180 hari atau lebih

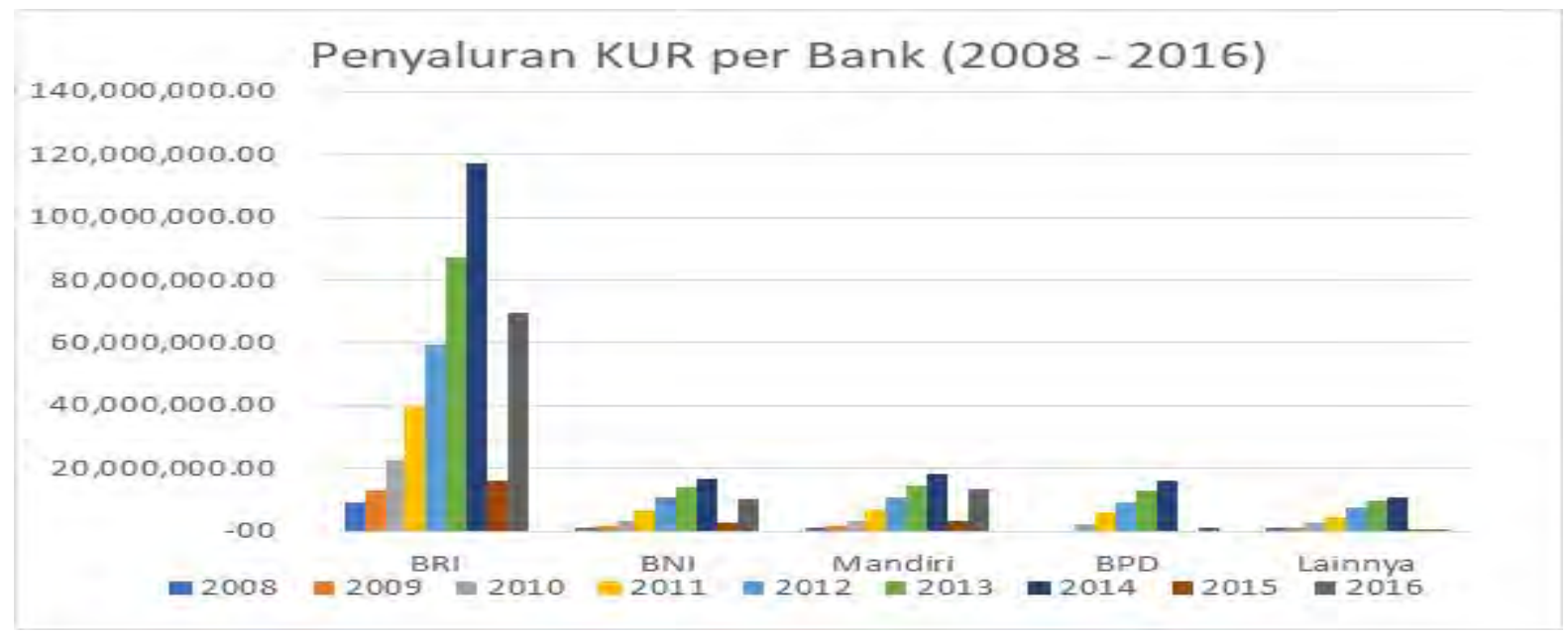

Gambar 2. Realisasi Penyaluran KUR Menurut Bank, 2008-2016

Sumber: Kemenko Bidang Ekonomi (Berbagai tahun, diolah)

nasabah KUR (existing borrowers) mereka. Kedua, penurunan suku bunga menekan cost of fund menjadi rendah sehingga nasabah terstimulasi mengajukan pinjaman dengan nominal yang lebih besar (Adam, 2017).

Berdasarkan lembaga keuangan pelaksana, seperti pada periode 2007-2014, BRI tetap menjadi leading bank dalam proses penyaluran KUR. Lebih dari itu, terdapat indikasi bahwa peran BRI dalam menyalurkan KUR mengalami peningkatan secara signifikan. Pada tahun 2014 dan 2016, penyaluran KUR melalui BRI meningkat dari 65,4\% (KUR Mikro 53,8\% dan KUR Ritel 11,6\%) menjadi 73,6\% (KUR Mikro
58,9\% dan KUR Ritel 12,3\%) dari total KUR (Gambar 2).

Keberhasilan BRI menjadi leading bank dalam penyaluran KUR tidak terlepas dari dukungan keuangan (financial capacity), kuatnya pemahaman, panjangnya pengalaman sebagai penyalur kredit mikro (micro credit business capability), dan terbangunnya kualitas sumber daya manusia (SDM) (TNP2K, 2015a). BRI juga memiliki komitmen yang kuat dengan pengembangan IT untuk meningkatkan konektivitas antar cabang, mempermudah transaksi dengan nasabah, dan memperluas jangkauan pelayanan sampai ke daerah-daerah terpencil. 


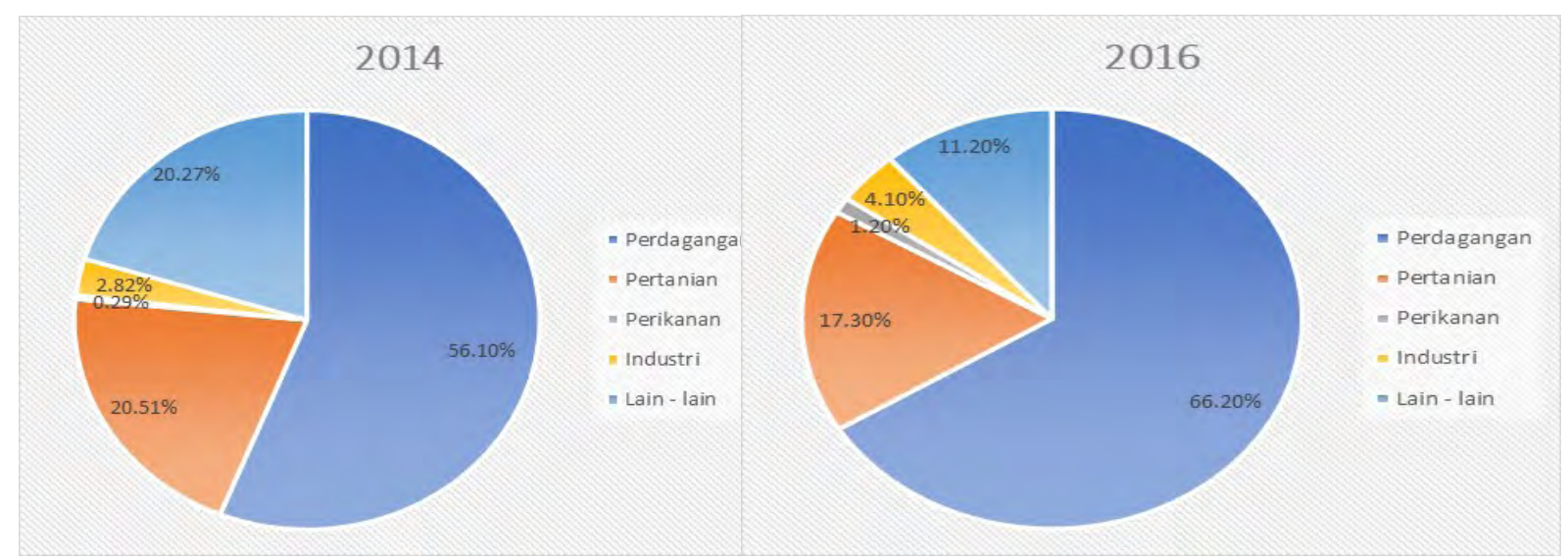

Gambar 3. Realisasi Penyaluran KUR Menurut Sektor, 2014 dan 2016

Sumber: Kemenko Bidang Ekonomi (2014, 2016, diolah)

Terkait dengan SDM, berbeda dengan bank lainnya, secara khusus BRI mengangkat account officer, biasa disebut mantri KUR sebagai ujung tombak penyaluran, pemasaran dan pencarian nasabah potensial. Struktur manajemen BRI juga lebih siap untuk menyalurkan KUR dengan memiliki BRI Unit yang khusus menyalurkan KUR Mikro, sementara KUR Ritel ditangani account officer di kantor cabang. Sistem reward and punishment dilaksanakan sebagai salah satu instrumen untuk menjaga kualitas account officer. Account officer yang gagal memenuhi target penyaluran KUR, baik plafon kredit ataupun jumlah nasabah hanya diberi satu kesempatan lagi. Sebaliknya, account officer yang selalu berhasil memenuhi target diberikan bonus dan berpeluang diangkat menjadi pegawai tetap BRI. Dengan sistem seperti itu, BRI mampu meningkatkan ekspansi kredit (KUR) tanpa memicu peningkatan risiko kredit bermasalah (NPL).

Secara sektoral, distribusi penyaluran KUR tahap pertama dan tahap kedua tetap bias terhadap sektor perdagangan. Indikasinya, porsi penyaluran KUR ke sektor perdagangan terus mengalami peningkatan dari 31,7\% (2009), 56,1\% (2014), dan 66,2\% (2016) dari total penyaluran KUR (Gambar 3). Karena itu, perdagangan muncul sebagai sektor yang semakin dominan menyerap alokasi KUR. Sebaliknya, porsi KUR untuk sektor produktif (sektor industri, pertanian, perkebunan, perikanan, dan peternakan) hanya meningkat pada periode $2009-2014$, dari $12,4 \%$ menjadi $21,3 \%$. Pada tahun 2016, porsi ini tetap berada di kisaran 21,3\%.
Pola penyaluran KUR, pada tahap baik pertama ataupun kedua, yang bias terhadap sektor perdagangan mengindikasikan bahwa persepsi lembaga keuangan pelaksana mengenai risiko tidak mengalami perubahan. TNP2K (2015a) menjelaskan preferensi perbankan memprioritaskan penyaluran KUR ke sektor perdagangan dilandasi persepsi bahwa sektor ini memiliki risiko yang relatif lebih rendah dibandingkan dengan sektorsektor ekonomi lainnya. Bagi perbankan, pendapatan harian yang relatif stabil di sektor perdagangan merupakan sinyal bahwa nasabah di sektor ini memiliki kemampuan mengembalikan pinjaman KUR tepat waktu dan tepat jumlah.

Hanya saja, beberapa studi menunjukkan perkembangan sektor produktif berperan strategis dalam pembangunan ekonomi disebabkan beberapa hal. Pertama, mampu menciptakan kesempatan kerja yang sangat luas. Kedua, backward dan forward linkagenya terhadap sektor ekonomi lain sangat tinggi. Ketiga, berkembangnya sektor produktif memungkinkan Indonesia menikmati secara optimal proses nilai tambah di dalam negeri. Dalam konteks penanggulangan kemiskinan, berkembangnya sektor produktif juga sangat vital. Sektor pertanian (termasuk perkebunan, perikanan, dan peternakan) menjadi kantong dan konsentrasi orang miskin. Karena itu, Adam (2010) menunjukkan pertumbuhan sektor pertanian dan industri mampu menekan kemiskinan masing-masing 4 dan 6,5 kali lebih kuat daripada sektor non-tradable, termasuk perdagangan. 

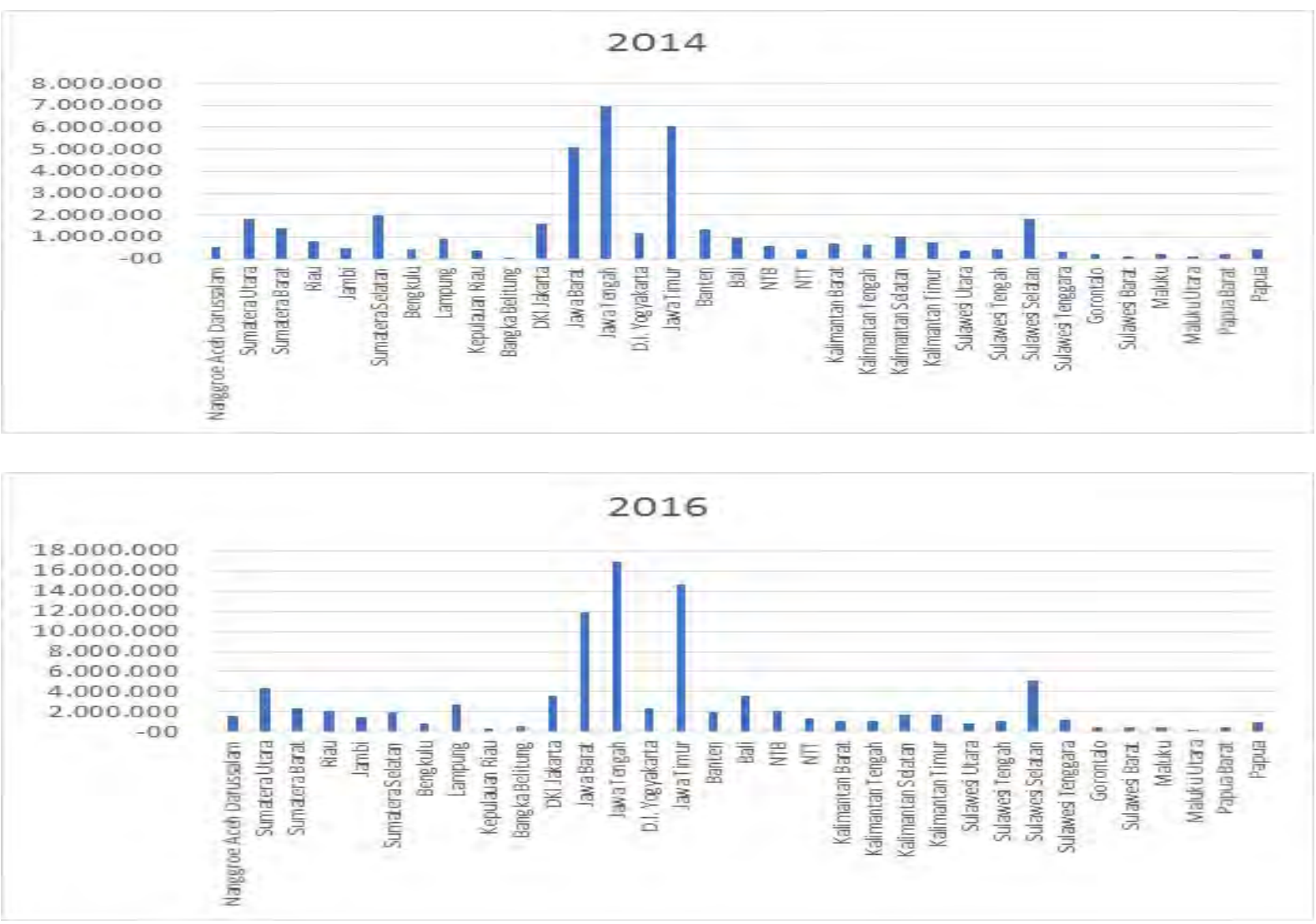

Gambar 4. Realisasi Penyaluran KUR Menurut Provinsi, 2014 dan 2016

Sumber: Kemenko Bidang Ekonomi (2014, 2016, diolah)

Strategisnya peran sektor produktif memotivasi pemerintah (Komite Kebijakan KUR) untuk memperbesar porsi KUR ke sektor-sektor itu. Sejak tahun 2017, pemerintah mentargetkan minimal $40 \%$ dari total KUR tersalur ke sektor produktif. Sayangnya, aturan untuk mendorong lembaga keuangan memenuhi target pemerintah masih diragukan efektivitasnya. Aturan yang diberlakukan adalah mengenakan sangsi pemotongan plafon KUR terhadap lembaga keuangan yang gagal mencapai target. Aturan ini diperkirakan tidak akan efektif karena beberapa lembaga keuangan berpandangan keterlibatan mereka dalam program KUR lebih karena 'penugasan' dari pemerintah dan cenderung lebih bermotif sosial. Bagi lembaga keuangan dalam kategori ini, keterlibatan mereka dalam program KUR sama sekali tidak memberikan insentif ekonomi, misalnya dengan menempatkan KUR sebagai profit centre atau ladang persemaian untuk memperluas basis nasabah kredit mikro komersial di masa depan.
Karena itu, penurunan plafon kredit akan dipandang sebagai berkah untuk mengelak dari 'penugasan' pemerintah.

Kebijakan perbedaan perlakuan sebenarnya bisa menjadi salah satu solusi untuk memperbesar porsi KUR ke sektor produktif. Kebijakan ini pernah diberlakukan pada KUR tahap pertama, dengan meningkatkan besaran penjaminan untuk sektor produktif menjadi $80 \%$, sedangkan untuk sektor perdagangan tetap sebesar $70 \%$. Pada KUR tahap kedua dimana pemerintah memberlakukan subsidi suku bunga, maka pilihan yang bisa diambil adalah: Pertama, memberikan subsidi bunga yang lebih besar, sehingga beban bunga nasabah di sektor produktif menjadi relatif lebih ringan. Kedua, subsidi bunga untuk sektor produktif besarnya sama dengan sektor perdagangan. Tetapi, pemerintah juga memberikan kompensasi terhadap tingginya risiko di sektor produktif dengan menyediakan subsidi penjaminan.

Dilihat dari sebaran geografisnya, KUR masih terkonsentrasi di Pulau Jawa dengan 
Tabel 3. Sumber Permodalan Usaha

\begin{tabular}{lccccccccccc}
\hline & \multicolumn{10}{c}{ Persentase Kredit Berdasarkan Desil (\%) } \\
\cline { 2 - 12 } & $\mathbf{1}$ & $\mathbf{2}$ & $\mathbf{3}$ & $\mathbf{4}$ & $\mathbf{5}$ & $\mathbf{6}$ & $\mathbf{7}$ & $\mathbf{8}$ & $\mathbf{9}$ & $\mathbf{1 0}$ & Total \\
\hline PNPM & 2,22 & 2,64 & 2,68 & 2,84 & 2,92 & 3,00 & 3,15 & 2,64 & 2,07 & 1,28 & 2,60 \\
KUR & 2,61 & 3,92 & 4,25 & 4,49 & 5,09 & 5,53 & 6,27 & 7,11 & 7,22 & 6,63 & 5,17 \\
Bank & 1,44 & 2,40 & 2,69 & 3,27 & 3,31 & 4,11 & 4,97 & 5,72 & 6,50 & 7,92 & 4,00 \\
KUBE & 0,49 & 0,51 & 0,53 & 0,53 & 0,44 & 0,49 & 0,47 & 0,51 & 0,63 & 0,41 & 0,50 \\
Koperasi & 2,56 & 2,55 & 3,06 & 2,78 & 3,13 & 2,76 & 3,60 & 3,29 & 3,14 & 2,65 & 2,95 \\
Lainnya & 3,95 & 4,47 & 4,83 & 4,55 & 4,89 & 4,72 & 4,70 & 4,55 & 4,13 & 3,53 & 4,47 \\
Tidak ada & 87,91 & 85,14 & 83,79 & 83,46 & 82,26 & 81,63 & 79,56 & 78,97 & 79,18 & 80,57 & 82,47 \\
Kredit & & & & & & & & & & & \\
Total & 100 & 100 & 100 & 100 & 100 & 100 & 100 & 100 & 100 & 100 & 100 \\
\hline
\end{tabular}

Sumber: BPS (2016), Survei Sosial Ekonomi Nasional (Susenas) 2016 (Diolah)

kecenderungan yang semakin menguat. Pada periode 2009-2016, porsi penyaluran KUR ke 6 (enam) provinsi di Pulau Jawa terus mengalami peningkatan dari 47,9\% (2009), $52,9 \%$ (2014), dan 54,4\% (2016) dari total plafon penyaluran KUR (Gambar 4.).

TNP2K (2012) menemukan bahwa ketersediaan lembaga keuangan di suatu daerah (desa) berkorelasi dengan tingginya akses terhadap KUR di daerah (desa) yang bersangkutan. Provinsi di Pulau Jawa rata-rata memiliki ketersediaan lembaga keuangan (bank) yang lebih memadai dibandingkan dengan provinsi di luar Pulau Jawa, seperti Kalimantan Barat, Maluku Utara, dan NTT. Karena itu, terlepas dari fakta bahwa secara agregat UMKM di Pulau Jawa relatif lebih banyak dibandingkan dengan UMKM di luar Jawa, terbatasnya ketersediaan lembaga keuangan, seperti unit dan cabang bank pelaksana di beberapa provinsi luar Pulau Jawa kemungkinan juga berkontribusi terhadap tidak terdistribusinya KUR secara proporsional ke seluruh provinsi.

UMKM di provinsi luar Pulau Jawa cenderung memproduksi barang dengan memanfaatkan sumber daya dan karakter lokal yang lebih kuat dibandingkan dengan UMKM di Jawa (Adam, 2009). Penggunaan sumber daya dan karakter lokal membuat keuntungan dari proses nilai tambah bisa secara optimal dinikmati bangsa ini. Karena itu, meningkatkan jangkauan program KUR ke provinsi di luar Pulau Jawa dengan memperluas basis lembaga keuangan pelaksana, seperti melibatkan koperasi, menjadi krusial sebagai instrumen pemberdayaan UMKM, pendorong pembangunan ekonomi, dan percepatan penanggulangan kemiskinan. Dalam kaitan dengan kemiskinan, argumentasinya adalah secara geografis, daerah di luar Pulau Jawa, khususnya IBT (Indonesia Bagian Timur), menjadi kantong-kantong kemiskinan yang kurang tersentuh oleh program-program penanggulangan kemiskinan.

\section{Peluang Dan Tantangan Pelibatan Koperasi Simpan Pinjam Dalam Program KUR}

Analisis terhadap pelaksanaan KUR pada bagian sebelumnya menyimpulkan terdapat dua alasan penting mengapa kebijakan melibatkan koperasi sebagai penyalur KUR menjadi sangat penting. Pertama, pada dua tahun pertama pelaksanaan KUR Tahap Kedua, lembaga keuangan pelaksana gagal mencapai target penyaluran KUR, khususnya KUR Mikro, yang ditetapkan. Karena itu, pelibatan koperasi diharapkan bisa menjadi amunisi tambahan untuk mencapai target penyaluran KUR Mikro. Kedua, membantu meningkatkan outreach KUR secara sektoral dan kewilayahan. Artinya, melibatkan koperasi diharapkan berdampak positif terhadap peningkatan porsi KUR yang tersalur ke sektor produktif dan lebih mampu menjangkau provinsi di luar Pulau Jawa.

Harapan bahwa koperasi mampu berkontribusi terhadap penyelesaian dua masalah KUR seperti di atas sangat relevan dikaitkan dengan fungsi dan peran koperasi selama ini. Koperasi adalah lembaga ekonomi yang paling dekat dan paling memahami kebutuhan serta permasalahan UMKM (Sarwoko, 2009). Lembaga ini memiliki sejarah yang cukup panjang berperan sebagai salah satu sumber permodalan UMKM (Djunaid dan Djunaid, 2002; Assa, Tampajara dan Endi., 2017). 
Tabel 4. Kondisi KSP di Indonesia, 2014

\begin{tabular}{|c|c|c|c|c|c|}
\hline Provinsi & $\underset{\text { (Unit) }}{\text { Jumlah KSP }}$ & $\begin{array}{c}\text { Jumlah yang } \\
\text { Aktif (Unit) }\end{array}$ & $\begin{array}{l}\text { Anggota } \\
\text { (Orang) }\end{array}$ & $\begin{array}{c}\text { Penilaian } \\
\text { Kesehatan }\end{array}$ & Aset (Rp Juta) \\
\hline $\begin{array}{l}\text { Primer \& Sekunder } \\
\text { Nasional }\end{array}$ & 76 & 53 & 205.881 & 34 & $4.246 .623,09$ \\
\hline Aceh & 87 & 61 & 21.735 & 42 & $224.070,06$ \\
\hline Sumatera Utara & 225 & 203 & 103.142 & 142 & $603.211,39$ \\
\hline Sumatera Barat & 178 & 147 & 18.846 & 39 & $138.968,57$ \\
\hline Riau & 44 & 35 & 3.799 & 25 & $71.902,87$ \\
\hline Jambi & 88 & 86 & 1.856 & 60 & $87.678,57$ \\
\hline Sumatera Selatan & 292 & 253 & 9.870 & 173 & $246.195,48$ \\
\hline Bengkulu & 75 & 65 & 6.917 & 45 & $226.761,13$ \\
\hline Lampung & 228 & 189 & 71 & 133 & $126.364,79$ \\
\hline Bangka-Belitung & 29 & 28 & 6.625 & 20 & $41.999,35$ \\
\hline Kepulauan Riau & 5 & 5 & 4.617 & 3 & $22.349,54$ \\
\hline DKI Jakarta & 472 & 429 & 23.784 & 294 & $1.711 .381,88$ \\
\hline Jawa Barat & 812 & 724 & 138.009 & 402 & $679.336,15$ \\
\hline Jawa Tengah & 1.306 & 1.134 & 376.130 & 790 & $3.862 .371,39$ \\
\hline Banten & 310 & 194 & 1.799 & 145 & $180.299,10$ \\
\hline Jawa Timur & 3.456 & 1.532 & 895.019 & 857 & $2.859 .805,28$ \\
\hline DI Jogyakarta & 240 & 154 & 110.423 & 124 & $378.711,37$ \\
\hline Bali & 578 & 493 & 72.370 & 368 & $456.771,02$ \\
\hline Nusa Tenggara Barat & 149 & 146 & 26.281 & 109 & $451.721,95$ \\
\hline Nusa Tenggara Timur & 426 & 412 & 164.781 & 304 & $328.143,77$ \\
\hline Kalimantan Barat & 400 & 138 & 676.007 & 72 & $3.579 .278,79$ \\
\hline Kalimantan Tengah & 70 & 65 & 5.453 & 39 & $22.146,48$ \\
\hline Kalimantan Selatan & 54 & 52 & 127.482 & 34 & $137.042,88$ \\
\hline Kalimantan Timur & 93 & 78 & 1.589 & 57 & $148.953,08$ \\
\hline Sulawesi Utara & 201 & 159 & 17.696 & 106 & $685.604,88$ \\
\hline Sulawesi Tengah & 53 & 37 & 8.549 & 25 & $194.090,38$ \\
\hline Sulawesi Selatan & 229 & 193 & 106.312 & 143 & $1.624 .854,21$ \\
\hline Sulawesi Tenggara & 114 & 108 & 2.982 & 81 & $68.363,29$ \\
\hline Gorontalo & 122 & 85 & 2.167 & 46 & $430.953,61$ \\
\hline Sulawesi Barat & 35 & 25 & 29.626 & 16 & $58.678,49$ \\
\hline Maluku & 97 & 92 & 1.589 & 59 & $63.192,22$ \\
\hline Maluku Utara & 45 & 32 & 5.169 & 20 & $35.759,26$ \\
\hline Papua & 174 & 128 & 396 & 92 & $117.356,97$ \\
\hline Papua Barat & 48 & 33 & 595 & 18 & $8.939,81$ \\
\hline TOTAL & 10.811 & 7.568 & 3.177 .567 & 4.917 & 24.119 .881 \\
\hline
\end{tabular}

Sumber: Kementerian Koperasi dan UKM (2014)

Data menunjukkan koperasi memang menjadi salah satu sumber permodalan andalan UMKM. Sebagian besar pengusaha, khususnya pengusaha mikro dan kecil, masih mengandalkan sumber permodalan sendiri atau mengandalkan pinjaman dari perorangan, keluarga, dan tetangga (Tabel 3). Tetapi, pengusaha yang telah berinteraksi dengan lembaga keuangan menempatkan koperasi sebagai alternatif sumber permodalan terpenting ketiga setelah KUR dan kredit komersial perbankan. Pada desil 1, 2, dan 3 , proporsi pengusaha yang mengandalkan koperasi bahkan lebih tinggi dibandingkan dengan yang mengandalkan perbankan.
Pada desil-desil itu, pengusaha yang terlibat kemungkinan terkategori UMK yang menjadi target penyaluran KUR Mikro.

Secara sektoral, Djunaid dan Djunaid (2002) dan Assa et al. (2017) menegaskan koperasi terbiasa dan memiliki pengalaman memberikan dukungan permodalan ke beberapa sektor tidak hanya perdagangan, tetapi juga pertanian, kerajinan, dan industri pengolahan. Kebiasaan dan pengalaman koperasi ini menjadi modal penting untuk memperbesar porsi penyaluran KUR ke beberapa sektor non-perdagangan.

Pada saat kunjungan lapangan, komitmen koperasi untuk mendukung sektor non- 
perdagangan, khususnya pertanian, tertangkap secara jelas di KSP Keling Kumang dan Balota. KSP Keling Kumang mendukung perkembangan kelapa sawit, sedangkan KSP Balota tertarik pada perkembangan tanaman kopi. Pertimbangan bahwa kedua komoditas itu menjadi sumber mata pencaharian sebagian besar anggota tampaknya memotivasi kedua KSP itu menaruh perhatian masing-masing pada sawit dan kopi. Misalnya, pengurus KSP Balota menunjukkan lebih dari 40\% anggotanya merupakan petani kopi. Karena itu, KSP ini lalu berinisiatif bekerjasama dengan Nestle memberikan bantuan bibit tanaman kopi yang jenis dan kualifikasinya sesuai dengan kebutuhan Nestle terhadap 1.000 orang petani anggota. Menariknya, petani yang mendapat bantuan bibit tidak diharuskan menjual hasil panen kopinya hanya ke Nestle.

Sementara itu, perhatian KSP Keling Kumang terhadap kelapa sawit dilakukan dengan mengembangkan value chain kelapa sawit, menggunakan konsep social conglomerate. Artinya, KSP Keling Kumang tidak hanya menyediakan pinjaman modal, tetapi - bekerjasama dengan Koperasi Produksi di bawah holding cooperative Keling Kumang — juga memberikan edukasi melalui sekolah lapang mengenai tata cara bertani sawit secara benar, membangun pabrik CPO untuk mengolah sawit, dan berperan sebagai pedagang penampung CPO yang dihasilkan anggota. Untuk lebih memudahkan pengembangan value chain, KSP Keling Kumang membentuk self help group (SHG) yang terdiri dari para petani sawit anggota KSP.

Inisiatif KSP Keling Kumang terlibat secara lansung dalam pembentukan dan pengembangan value chain didorong kondisi dimana petani sawit yang jadi anggota KSP sering tidak mampu mengembalikan pinjaman tepat waktu dan tepat jumlah. Dari perspektif KSP, ketidakmampuan petani sawit mengembalikan pinjaman merupakan akumulasi dari permasalahan yang mereka hadapi baik pada saat budidaya (produktivitas rendah karena menggunakan bibit yang kurang baik dan pemeliharaan yang kurang maksimal) maupun pada saat pemasaran (penurunan harga).
Selain diharapkan berkontribusi terhadap peningkatan porsi penyaluran KUR untuk sektor non-perdagangan, KSP juga memiliki potensi meningkatkan porsi penyaluran KUR ke daerah di luar Pulau Jawa. Secara geografis, koperasi, khususnya Koperasi Simpan Pinjam (KSP) memang tersebar di seluruh provinsi. Pada tahun 2014, terdapat 10.811 KSP dimana $70 \%$ diantaranya $(7.568$ KSP) aktif menghimpun dana dan kemudian menyalurkan kembali dana tersebut kepada anggota. Dari 7.568 KSP yang aktif, lebih dari $45 \%$ berlokasi di luar Pulau Jawa (Tabel 4).

Tabel 4 juga memperlihatkan terdapat sekitar 3,1 juta anggota yang bisa melakukan kegiatan simpan-pinjam di KSP. Jumlah anggota KSP, khususnya yang berprofesi sebagai pengusaha UMKM merupakan calon nasabah potensial KUR. Sesuai dengan aturan koperasi, dengan menggunakan jalur KSP, maka KUR dipastikan hanya akan tersalur ke UMKM anggota.

Dalam kaitan dengan karakter anggota, salah satu temuan yang menarik adalah indikasi bahwa anggota yang diwawancarai di seluruh KSP yang dikunjungi sangat loyal dan menaruh kepercayaan yang tinggi terhadap KSP-nya. Meskipun banyak pilihan lembaga keuangan sebagai tempat simpan-pinjam dengan menawarkan keuntungan ekonomi yang lebih baik, mereka enggan melepas keanggotaannya sebagai nasabah KSP. Keterikatan sejarah karena pernah 'dibantu' pada saat sulit dan terjepit membuat mereka menjadi loyal. Tidak jarang mereka kemudian mengajak anak dan cucunya menjadi anggota KSP yang pernah 'membantunya'.

Terdapat dua keuntungan dari pola hubungan KSP yang dipercaya vis-à-vis nasabah yang loyal. Pertama, sebagaimana terjadi di KSP Obor Mas, pada saat RAT, KSP bisa mengusulkan penetapan suku bunga simpanan secara wajar, berada pada kisaran yang setara dengan suku bunga simpanan perbankan. Bunga simpanan yang wajar memungkinkan KSP Obor Mas menekan cost offund dan memiliki ruang untuk menetapkan suku bunga pinjaman yang bisa bersaing dengan suku bunga pinjaman perbankan.

Kedua, KSP menterjemahkan bankability calon debitur tidak fokus hanya kepada mampu-tidaknya mereka menyediakan 
agunan, tetapi lebih luas dengan melihat track record, kerajinan menabung, dan karakter sosial-ekonomi lainnya. Salah satu faktor penghambat UMKM dalam mengakses kredit perbankan, termasuk KUR, adalah ketidakmampuan menyediakan agunan. Jika proses penentuan nasabah peminjam di KSP tidak fokus hanya ke penyediaan agunan, maka KSP memiliki potensi untuk meningkatkan outreach KUR dengan menyasar UMKM anggota yang divonis bank tidak bankable karena tidak mampu menyediakan agunan.

Penting untuk dikemukakan, meskipun khusus hanya untuk anggota, tetapi tidak semua anggota memiliki kesempatan yang sama untuk memanfaatkan KUR. Berdasarkan aturan dan ketentuan sebagaimana telah dijelaskan pada bagian sebelumnya, sasaran utama KUR adalah UMKM yang berusaha di sektor produktif dan telah menjalankan usahanya secara feasible, tetapi masih unbankable. Dengan demikian, KSP yang terlibat dalam program KUR harus melakukan seleksi terhadap UMKM anggota yang memiliki karakter yang sesuai dengan ketentuan KUR.

Keharusan melakukan seleksi terhadap UMKM anggota menjadi bahan perdebatan di kalangan anggota dari beberapa KSP yang dikunjungi. Forum Rapat Anggota Tahunan (RAT) di beberapa KSP, seperti di Pancur Kasih, bahkan memutuskan menunda keterlibatan dalam program KUR karena mereka keberatan jika mekanisme penyaluran KUR didasarkan kepada proses seleksi untuk menentukan mana UMKM anggota yang feasible dan tidak feasible mendapatkan KUR. Keputusan itu diambil karena RAT KSP Pancur Kasih menyimpulkan bahwa KSP-nya dibangun dan dikembangkan berlandaskan 3 pilar penting, yaitu pendidikan, swadaya, dan solidaritas ${ }^{1}$. Proses seleksi menurut kesimpulan RAT akan menciderai prinsip swadaya dan solideritas karena UMKM anggota tidak akan memiliki kesempatan yang sama untuk mengakses KUR.

\footnotetext{
Pilar pendidikan diterjemahkan kedalam visi dengan berkembang dengan pendidikan, dikontrol oleh pendidikan, dan bergantung pada pendidikan. Pilar swadaya diterjemahkan semua kekuatan berasal dari anggota, oleh anggota, dan untuk anggota. Pilar solideritas diterjemahkan sebagai anda sulit saya bantu, saya sulit anda bantu.
}

Penundaan keterlibatan KSP Pancur Kasih untuk berpartisipasi dalam program KUR juga disebabkan keputusan RAT 2016 yang menyimpulkan bahwa subsidi baik secara praktis maupun filosofis mengandung permasalahan. Pada tataran praktis, mekanisme proses pembayaran subsidi dari pemerintah kepada lembaga keuangan penyalur KUR masih sangat kompleks sehingga selalu mengalami keterlambatan. Jika proses pembayaran subsidi ini tidak mengalami perbaikan, maka hal ini bisa mengganggu struktur keuangan KSP.

Secara filosofis, subsidi bunga yang menjadi karakter KUR Tahap Kedua akan menggerus pilar swadaya. Pemberian subsidi dari pemerintah akan mengurangi derajat swadaya Pancur Kasih karena subsidi diterjemahkan sebagai suntikan dana dari pihak luar. Lebih dari itu, dengan mendapatkan subsidi bunga, maka Pancur Kasih menjadi kurang independen dalam proses penentuan suku bunga, pemilihan calon nasabah, dan penentuan sektor prioritas.

Kasus yang bertolak belakang terjadi di KSP Keling Kumang, Balota dan Obor Mas. RAT di ketiga KSP itu justru mendorong agar mereka bisa segera berpartisipasi dalam program KUR. Dari perspektif ketiga KSP, paling tidak terdapat dua pertimbangan yang memotivasi mereka tertarik melibatkan diri sebagai penyalur KUR. Pertama, meningkatkan reputasi dan status mereka sebagai lembaga yang memiliki kapasitas menjalankan bisnis pada level yang sama dengan perbankan. Peningkatan reputasi dan status ini akan memudahkan mereka untuk menarik tidak saja anggota baru, tetapi juga pihak ketiga (anggota luar biasa) yang ingin berinvestasi.

Kedua, memungkinkan KSP memperluas pasar dengan memberikan pinjaman kepada anggota/calon anggota yang selama ini lebih suka meminjam ke bank. Suku bunga KUR yang ditawarkan perbankan dan koperasi akan berada pada angka yang persis sama. Ini akan menjadi daya tarik bagi anggota/ calon anggota yang selama ini melihat suku bunga pinjaman koperasi jauh lebih mahal dibandingkan dengan suku bunga pinjaman perbankan. 
Secara filosofis, KSP Keling Kumang, Balota dan Obor Mas tertarik terlibat dalam program KUR karena berbeda pandangan dengan KSP Pancur Kasih. Ketiga KSP itu sepakat bahwa selain pendidikan, swadaya, dan solidaritas, KSP memiliki dua pilar tambahan, yaitu inovasi dan persatuankesatuan. Dua pilar tambahan memberi ruang kepada KSP untuk berinovasi dan beradaptasi dengan dinamika kegiatan simpan-pinjam - seperti diversifikasi produk simpan-pinjam, sumber pendanaan dan penggunaan IT - sepanjang sesuai dengan kebutuhan dan berdampak secara positif terhadap peningkatan kesejahteraan anggota. Inovasi membuat ketiga KSP memiliki produk pinjaman yang lebih variatif dan mampu menjalin kerjasama dengan pihak ketiga yang menyimpan dananya di KSP untuk memperkuat struktur permodalan.

Seperti ketiga KSP tersebut di atas, dengan alasan sebagai bagian dari upaya untuk berinovasi dan beradaptasi dengan dinamika simpan-pinjam dalam rangka memberi pelayanan yang lebih optimal kepada anggota, Kospin Jasa sebagai KSP pertama yang mendapat kewenangan berperan sebagai penyalur KUR juga memperkuat struktur aset dan permodalan melalui kerjasama dengan pihak ketiga. Struktur permodalan yang kuat membuat Kospin Jasa mampu melakukan ekspansi dengan mendirikan kantor cabang di Lampung, semua provinsi di Pulau Jawa, dan Bali. Asset dan struktur permodalan yang kuat juga memungkinkan Kospin Jasa mengembangkan teknologi IT secara lebih modern. Interkoneksi antar cabang dan kerjasama dengan visa card memudahkan anggota dalam melakukan transaksi. Di Pekalongan dan beberapa kantor cabang lainnya, Kospin Jasa muncul sebagai saingan yang serius bagi sektor perbankan.

Bersamaan dengan penerbitan SK untuk Kospin Jasa, Komite Kebijakan KUR juga memberikan SK kewenangan kepada KSPS (KSP Syariah) Sidogiri untuk berperan sebagai penyalur KUR. Sayangnya, KSPS Sidogiri mundur di tengah jalan karena alasan disain KUR belum secara jelas mengakomodasi proses bisnis yang dijalankan secara Syariah. Permenko Bidang Ekonomi No. 9/2016 sebenarnya telah secara eksplisit menegaskan bahwa koperasi yang menjadi target utama untuk dilibatkan dalam program KUR adalah KSP dan KSPS. Hanya saja, Permenko (dan peraturan-peraturan lainnya), tidak memberi penjelasan teknis bagaimana mengkonversi subsidi suku bunga kedalam instrumen yang bisa diterima secara Syariah.

Terlepas dari permasalahan di atas, meskipun memiliki potensi untuk berkontribusi terhadap peningkatkan outreach KUR secara sektoral dan kewilayahan, upaya untuk mendorong keterlibatan KSP dalam program KUR perlu dilakukan secara hati-hati. Beberapa studi (e.g. Noordiansyah, 2010; Gustifa, 2013; Sihombing, 2016) memperlihatkan tidak sedikit KSP yang memiliki NPL (non-performing loans) jauh di atas 5\%. Tingginya NPL mengindikasikan bahwa KSP kebanyakan belum memiliki manajemen risiko yang baik yang bisa digunakan sebagai instrumen untuk mengontrol dan meminimalisir pinjaman (kredit) bermasalah.

Lebih dari itu,sebagaimana bisa dilihat di Tabel 4, pada tahun 2014, 30\% dari total KSP (3.243 KSP) tidak aktif beroperasi. Banyaknya KSP yang tidak aktif menunjukkan bahwa mereka menghadapi beberapa permasalahan. Berdasarkan diskusi yang dilakukan dengan beberapa KSP pada saat field visit, teridentifikasi 5 permasalahan utama yang seringkali mengganggu atau bahkan menghentikan operasional KSP (Tabel $5)$.

Beberapa KSP sebenarnya sudah berinovasi untuk mengatasi beragam permasalahan yang teridentifikasi. Misalnya, untuk memperkuat struktur permodalan, beberapa KSP mengundang pihak ketiga untuk berinvestasi. Di KSP Kospin Jasa dan Balota, aturan bahwa modal koperasi harus bersumber dari anggota disiasati dengan melabeli pihak ketiga sebagai anggota luar biasa. Beberapa KSP, seperti Keling Kumang dan Obor Mas, juga telah menciptakan variasi produk pinjaman yang memudahkan anggotanya untuk melakukan transaksi simpan-pinjam. Di beberapa KSP, penciptaan variasi produk dibarengi dengan upaya merekrut tenaga pemasaran, account officers. Seperti di beberapa perbankan, seorang account officer KSP juga memiliki target 
Tabel 5. Beberapa Permasalahan yang Dihadapi KSP

\begin{tabular}{|c|c|}
\hline Permasalahan & Penyebab \\
\hline Rendahnya kemampuan & a) Hanya mengandalkan iuran dan simpanan dari anggota \\
\hline menghimpun dana & $\begin{array}{l}\text { b) Kurangnya variasi produk simpanan yang menarik bagi } \\
\text { anggotanya } \\
\text { c) Lemah melakukan keriasama dengan pihak ketiga }\end{array}$ \\
\hline $\begin{array}{l}\text { Rendahnya kemampuan } \\
\text { menyalurkan dana }\end{array}$ & $\begin{array}{l}\text { a) Terbatasnya kemampuan dan kurangnya pengalaman SDM } \\
\text { untuk melakukan diversifikasi serta variasi produk pinjaman } \\
\text { lintas sektor }\end{array}$ \\
\hline $\begin{array}{l}\text { Lemahnya manajemen } \\
\text { operasional }\end{array}$ & $\begin{array}{l}\text { a) Sering sangat tergantung kepada beberapa pengurus tertentu } \\
\text { b) Lambat melakukan regenerasi dalam struktur kepengurusan }\end{array}$ \\
\hline Rendahnya kemampuan & a) Sangat bergantung pada kemampuan dan komitmen anggota \\
\hline menciptakan laba & $\begin{array}{l}\text { b) Kurangnya kapasitas Pengelola/Pengurus KSP dalam } \\
\text { menetapkan biaya (cost) dan harga (price) untuk produk-produk } \\
\text { simpan pinjam yang dimilikinya }\end{array}$ \\
\hline $\begin{array}{l}\text { Rendahnya transparansi dan } \\
\text { akuntabilitas }\end{array}$ & $\begin{array}{l}\text { a) Terbatasnya kemampuan untuk membuat dokumen perencanaan } \\
\text { dan pelaporan }\end{array}$ \\
\hline
\end{tabular}

Sumber: Hasil Diskusi dengan Beberapa KSP

terkait dengan jumlah uang yang harus disalurkan dan jumlah nasabah baru yang harus direkrut.

\section{Kriteria Untuk KSP/KSPS Penyalur KUR}

Permenko Bidang Ekonomi No. 9 tahun 2016 tentang perubahan kedua atas Permenko Bidang Ekonomi No 8 tahun 2015 tentang pedoman pelaksanaan KUR adalah landasan hukum yang mengatur keterlibatan KSP dan KSPS dalam program KUR. Tujuan utama pelibatan KSP/KSPS dalam program KUR menurut Permenko adalah untuk meningkatkan dan memperluas pelaksanaan penyaluran KUR serta mendorong pertumbuhan ekonomi. Permenko juga menegaskan bahwa KSP/KSPS yang ditarget untuk dilibatkan dalam program KUR adalah mereka yang mendapat ijin usaha dan ada dibawah pengawasan Kemenkop dan UKM.

Secara teknis, prosedur yang harus dilalui oleh KSP/KSPS untuk menjadi penyalur dimulai ketika suatu KSP/KSPS mengajukan usulan sebagai penyalur KUR ke Kementerian Koperasi dan UKM serta OJK. Sebagaimana diatur melalui Pasal $4 \mathrm{~b}$, terdapat 8 tahap yang harus dilalui oleh KSP/KSPS dengan melibatkan tiga institusi yaitu, Kementerian Koperasi dan UKM (Kemenkop), OJK, serta Kementerian Keuangan (Kemenkeu) ${ }^{2}$.

\footnotetext{
${ }^{2}$ 1) Koperasi/Lembaga Keuangan mengajukan proposal keikutsertaan kepada Kemenkop/OJK. Kemenkop berkoordinasi dengan OJK menganalisis tingkat kesehatan dan kinerja koperasi/lembaga keuangan. Jika penilaian Kemenkop dan OJK menyatakan
}

Berhasil tidaknya KSP/KSPS menjadi penyalur pada akhirnya ditentukan oleh kemampuan KSP/KSPS memenuhi beberapa persyaratan. Melalui Pasal 4 (2) dan Pasal

bahwa koperasi/lembaga keuangan belum memenuhi persyaratan, berbagai langkah perbaikan perlu dilakukan oleh koperasi/lembaga keuangan dengan bimbingan Kemenkop dan OJK. Jika Kemenkop dan OJK menilai koperasi/lembaga keuangan yang bersangkutan telah memenuhi syarat, Kemenkop dan OJK akan menginformasikan hal tersebut kepada koperasi/lembaga keuangan yang bersangkutan. 2) Jika Kemenkop dan OJK menilai bahwa koperasi/ lembaga keuangan yang bersangkutan sudah siap berpartisipasi dalam Program KUR, koperasi/lembaga keuangan diminta mengajukan permohonan kepada Kemenkeu untuk melakukan tes sistem informasi online agar terhubung dengan SIKP. 3) Jika sistem informasi koperasi/lembaga keuangan belum bisa terhubung dengan SIKP, koperasi/lembaga keuangan tersebut akan bekerjasama dengan Kemenkeu untuk mengembangkan sistem IT . 4) Jika sistem IT koperasi/lembaga keuangan berhasil tersambung dengan SIKP, Kemenkeu akan menginformasikan hal tersebut kepada Kemenkop dan OJK. 5) Secara bersamaan, Kemenkeu juga akan menginformasikan hal tersebut kepada Komite Kebijakan KUR. 6) Koperasi/Lembaga Keuangan wajib menjalin kerjasama dengan Lembaga Penjamin KUR yang telah ditunjuk oleh Komite Kebijakan KUR, hingga Perjanjian Kerjasama (PKS) dengan Lembaga Penjamin KUR ditandatangani. 7) Jika PKS antara koperasi/lembaga keuangan dengan Lembaga Penjamin KUR sudah ditanda tangani, Kemenkop merekomendasikan keikutsertaan koperasi/lembaga keuangan yang bersangkutan sebagai Lembaga Penyalur KUR kepada Komite Kebijakan Program KUR. 8) Penandatangan PKS antara koperasi/lembaga keuangan dengan Kementerian Koordinator bidang Perekonomian selaku Ketua Komite Kebijakan KUR dan Kemenkop sebagai KPA program KUR 
4a (1b), Permenko menguraikan empat persyaratan yang harus dipenuhi lembaga keuangan, termasuk KSP/KSPS, agar bisa berperan sebagai penyalur KUR. Pertama, memiliki kinerja yang sehat dan baik. Kedua, memiliki teknologi informasi yang tersambung (online) dengan SIKP. Ketiga, bekerjasama dengan perusahaan penjamin KUR yang telah ditunjuk oleh Komite Kebijakan KUR. Keempat, melakukan kerjasama pembiayaan dengan pemerintah (Kemenkop sebagai pemegang Kuasa Pengguna Anggaran/KPA program KUR).

Sayangnya, Permenko belum secara detail menjelaskan teknis operasional mengenai persyaratan-persyaratan seperti tersebut di atas. Misalnya, Permenko belum mengatur dan mendefinisikan apa yang dimaksud dengan KSP/KSPS yang berkinerja sehat dan baik. Informasi dari Kemenkop dan UKM serta OJK menjelaskan bahwa KUR adalah produk perbankan. Karena itu, penyalur KUR termasuk KSP/KSPS dikategorikan sehat dan baik jika mampu mengikuti aturan-aturan microprudentials perbankan, seperti NPL, CAR, ataupun LDR. Permasalahannya adalah, motif dan proses bisnis koperasi tidak persis sama seperti perbankan. Karena itu, mencari persyaratan yang sesuai dengan karakteristik koperasi dan sejalan dengan aturan-aturan KUR menjadi krusial dalam mendorong keterlibatan KSP/KSPS sebagai penyalur KUR.

Berdasarkan tinjauan terhadap aturanaturan KUR, diskusi dengan narasumber dari Kemenkop dan UKM, OJK, dan Kemenko Bidang Ekonomi, serta kunjungan dan wawancara dengan beberapa KSP/KSPS terpilih, terdapat 4 persyaratan penting yang harus dipenuhi KSP/KSPS agar bisa terlibat sebagai penyalur KUR. Keempat persyaratan itu adalah sebagai berikut:

\section{Aset Usaha dan Kecukupan Modal}

Dana program KUR yang disalurkan melalui lembaga keuangan, termasuk KSP/ KSPS, sepenuhnya merupakan dana pihak ketiga (DPK) milik lembaga keuangan yang bersangkutan. Pemerintah hanya menyediakan insentif melalui pemberian subsidi suku bunga sebesar $10 \%$, yang didalamnya sudah mencakup IJP (imbal jasa penjaminan) sebesar 1,5\%. IJP ini harus dibayar lembaga keuangan penyalur KUR kepada perusahaan asuransi penjaminan (seperti Askrindo dan Jamkrindo) melalui mekanisme business to business pada saat terjadi transaksi kredit diantara lembaga keuangan pelaksana dengan nasabahnya.

Permasalahannya adalah, proses pencairan subsidi suku bunga cenderung masih kompleks karena mekanismenya terbangun melalui interaksi dan komunikasi diantara 4 lembaga, yaitu: Pengelola SIKP (Kementerian Keuangan), Lembaga Keuangan Penyalur, Komite Kebijakan KUR, dan KPA Program KUR (Kementerian Koperasi dan UKM) (Gambar 5). Karena itu, seperti yang terjadi di Tahun 2016, lembaga keuangan penyalur baru mendapatkan subsidi dari pemerintah ketika tahun fiskal sudah memasuki kuartal ke 4 .

Berdasarkan mekanisme seperti di Gambar 5, KSP/KSPS yang ingin terlibat sebagai penyalur KUR harus memiliki aset bisnis dan struktur permodalan yang kuat. Jika tidak, maka KSP/KSPS yang terlibat akan mengalami kesulitan untuk menata struktur keuangannya. Pada gilirannya, ini akan membuat KSP/KSPS yang terlibat tidak akan memiliki ruang yang cukup untuk mendukung keberlanjutan program pinjaman regular yang sudah lama digelutinya.

Keharusan memiliki struktur keuangan yang kuat sangat konstekstual dikaitkan dengan IJP yang harus dibayar ketika transaksi KUR terjadi. IJP memaksa KSP/KSPS untuk bisa mengalokasikan dana dengan nominal yang lebih besar dibandingkan dengan target penyaluran KUR. Artinya, ketika satu KSP/KSPS, seperti Kospin Jasa misalnya, ditarget untuk menyalurkan KUR sebesar Rp 50 milyar, maka ia sebenarnya harus mengalokasikan Rp 50 milyar plus IJP sebesar Rp 750 juta (1,5\% kali Rp 50 milyar).

Sayangnya, tidak diperoleh data mengenai struktur permodalan dari KSP/ KSPS yang dikunjungi. Namun demikian, dengan menggunakan aset bisnis sebagai proxy dari struktur permodalan, terdapat indikasi bahwa struktur permodalan $\mathrm{KSP} /$ KSPS yang dikunjungi sangat bervariasi. Kospin Jasa memiliki aset sampai dengan Rp 7 trilyun, tertinggi diantara KSP/KSPS yang dikunjungi. Sebaliknya, Balota hanya 


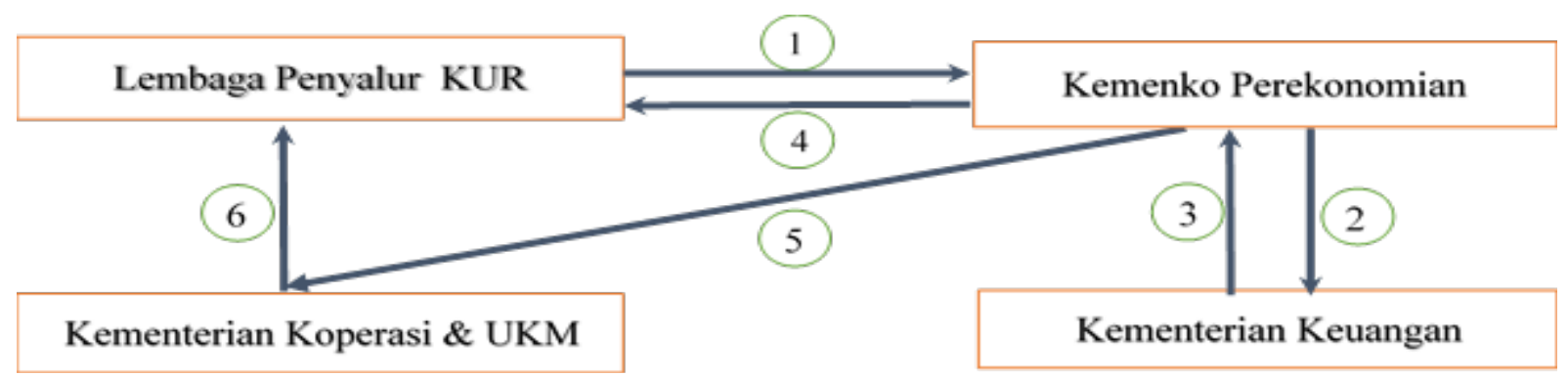

Gambar 5. Proses Pembayaran Subsidi Bunga dari Pemerintah ke Lembaga Penyalur KUR

Sumber: Kemenko Bidang Ekonomi (2016)

\section{Keterangan:}

1. Lembaga penyalur KUR mengajukan klaim kepada Komite Kebijakan KUR, melalui Kemenko Perekonomian selaku Ketua Komite Kebijakan KUR, untuk pembayaran subsidi bunga dari pinjaman KUR yang telah disalurkan

2. Komite Kebijakan KUR, melalui Kementerian Keuangan sebagai pengelola SIKP untuk memastikan bahwa klain yang diajukan oleh Lembaga Penyalur sesuai dengan data yang diunggah di SIKP

3. Kementerian Keuangan akan menginformasikan Kemenko Perekonomian apakah data sudah sesuai atau belum

4. Jika data belum sesuai, Kemenko Perekonomian akan menginformasikan hal ini kepada Lembaga Penyalur dan harus dilengkapi oleh Lembaga Penyalur agar subsidi dapat dibayarkan

5. Jika data sudah sesuai, Kemenko Perekonomian akan menginformasikan hal ini kepada Kementerian Koperasi dan UKM sebagai Kuasa Pengguna Anggaran (KPA) program KUR

6. Kementerian Koperasi dan UKM akan membauyarkan klaim sesuai dengan informasi dari Kemenko Perekonomian kepada Lembaga Penyalur

Tabel 6. Profil KSP yang dikunjungi

\begin{tabular}{lccccccc}
\hline Koperasi & $\begin{array}{c}\text { Tahun } \\
\text { Berdiri }\end{array}$ & $\begin{array}{c}\text { Asset } \\
\text { Usaha } \\
\text { (dalam } \\
\text { miliar IDR) }\end{array}$ & $\begin{array}{c}\text { Jumlah } \\
\text { Anggota }\end{array}$ & $\begin{array}{c}\text { Jumlah } \\
\text { Kantor } \\
\text { Perwakilan }\end{array}$ & $\begin{array}{c}\text { Jumlah } \\
\text { Provinsi }\end{array}$ & $\begin{array}{c}\text { Sistem Online } \\
\text { Wilayah } \\
\text { Kengan kantor }\end{array}$ & NPL \\
cabang & \\
\hline Kospin Jasa & 1973 & 7.000 & 25.000 & 163 & 6 & Ya & $3,19 \%$ \\
Balo' Toraja & 1937 & 400 & 250.000 & 38 & 5 & Tidak & $3,52 \%$ \\
Pancur Kasih & 1987 & 2.200 & 140.000 & 46 & 1 & Tidak & N.A. \\
Kredit Obor Mas & 1972 & 520 & 54.200 & 9 & 1 & Ya & $3,58 \%$ \\
Keling Kumang & 1993 & 1.300 & 165.000 & 61 & 1 & Ya & $9,71 \%$ \\
Sidogiri & 2000 & 1.800 & 12.900 & 277 & 10 & Ya & $<3 \%$ \\
\hline
\end{tabular}

Sumber: Hasil Wawancara

memiliki aset sebesar Rp 400 milyar (Tabel 6).

Penting dikemukakan bahwa agar bisa menjaga kesehatan keuangan dan keberlanjutan bisnisnya, idealnya target penyaluran KUR untuk KSP/KSPS ditetapkan berdasarkan indikator yang jelas. Dengan menjadikan beberapa bank penyalur KUR sebagai benchmark, dan menempatkan rasio target penyaluran KUR terhadap aset bisnis sebagai indikator kesehatan keuangan, rasio di bank penyalur ada di kisaran 0,82\% (BPD) sampai dengan 7\% (BRI) (Tabel 7).

Kapasitas keuangan KSP/KSPS kemungkinan lebih mendekati BPD daripada bank umum (BRI dan Mandiri). Jangkauan bisnis kebanyakan KSP/KSPS dengan konsentrasi di beberapa kabupaten/kota dalam satu provinsi, atau melakukan ekspansi maksimal di 6 provinsi membuat BPD lebih comparable dijadikan patokan dibandingkan dengan bank umum. Karena itu, menjadikan rasio target penyaluran KUR terhadap aset bisnis BPD sebagai benchmark cukup logis dan rasional dalam proses penetapan target penyaluran KUR oleh KSP/KSPS.

Tabel 7 memperlihatkan di satu sisi, target penyaluran KUR Kospin Jasa masih memiliki ruang untuk ditingkatkan karena masih lebih rendah dibandingkan dengan rasio BPD. Di sisi lain, target penyaluran KUR Obor Mas terkesan terlalu ambisius. Sebagaimana bisa 
Tabel 7. Rasio Target Penyaluran KUR Terhadap Aset di Beberapa Lembaga Keuangan Penyalur

\begin{tabular}{lccc}
\hline \multicolumn{1}{c}{ Lembaga Keuangan Penyalur } & $\begin{array}{c}\text { Total Aset } \\
\text { (Miliar Rp) }\end{array}$ & $\begin{array}{c}\text { Target Penyaluran KUR 2016 } \\
\text { (Miliar Rp) }\end{array}$ & Rasio \\
Bank & & & \\
\hline BRI & 964,000 & 67,500 & $7.00 \%$ \\
Bank Mandiri & 918,200 & 13,000 & $1.42 \%$ \\
BPD & 303,184 & 2,500 & $0.82 \%$ \\
KSP/KSPS & & & \\
Kospin Jasa** & 7,000 & 50 & $0.71 \%$ \\
Kopdit Obor Mas** & 520 & 100 & $19.23 \%$ \\
\hline
\end{tabular}

Sumber: Hasil perhitungan

di lihat di Tabel 7, rasio target penyaluran KUR terhadap aset bisnis Obor Mas mencapai angka 19,23\%, jauh lebih tinggi bahkan jika dibandingkan dengan rasio BRI sebesar 7\%.

Berdasarkan kasus yang terjadi di Kospin Jasa dan Obor Mas, diperlukan pertimbangan yang lebih terukur dan bijaksana dalam proses penentuan target penyaluran KUR dari masing-masing KSP/KSPS yang terlibat. Target penyaluran KSP/KSPS harus logis dan realistis sehingga mampu mendorong peningkatan dan perluasan penyaluran KUR tanpa memberi dampak negatif terhadap stabilitas dan kesehatan keuangan KSP/KSPS yang terlibat.

\section{Tata Kelola Bisnis}

Dalam kaitan dengan tata kelola bisnis, terdapat beberapa isu yang bisa menjadi kriteria dalam menentukan bisa-tidaknya suatu KSP/KSPS berperan sebagai penyalur KUR. Pertama, memiliki sejarah dan pengalaman mengelola dan menyalurkan kredit (pinjaman) mikro yang sifatnya produktif. Sebagian besar KSP/KSPS yang dikunjungi telah memiliki pengalaman yang cukup panjang dalam menyalurkan kredit mikro yang produktif. Namun demikian, kunjungan lapangan juga menemukan $\mathrm{KSP} / \mathrm{KSPS}$ dengan struktur pinjaman yang masih didominasi pinjaman konsumtif. Mengandalkan KSP/KSPS yang terbiasa mengelola kredit konsumtif sebagai penyalur KUR sangat berisiko karena sifat, karakter, dan perlakuan dalam mengelola kredit produktif cenderung berbeda dengan kredit konsumtif.

Kedua, memiliki cakupan wilayah kerja yang bisa dikontrol dengan baik. Tabel 6 memperlihatkan wilayah kerja KSP/KSPS yang dikunjungi berbeda diantara satu dengan yang lainnya. Sebagian KSP memiliki wilayah kerja sampai ke luar provinsi dimana kantor pusat KSP/KSPS itu berlokasi. Sebagian lainnya terkonsentrasi di beberapa kabupaten/kotamadya dalam satu provinsi yang sama dengan kantor pusat KSP/KSPS. Dalam kaitan ini, perlu pembagian tugas dan kewenangan yang jelas diantara kantor pusat dengan kantor cabang. Misalnya, apakah kewenangan persetujuan pemberian KUR sampai dengan Rp 25 juta bisa diputuskan hanya oleh kantor cabang atau kantor cabang harus mengkomunikasikan keputusannya terlebih dahulu dengan kantor pusat. Isu ini sangat konstektual dikaitkan dengan temuan lapangan dimana terdapat beberapa $\mathrm{KSP} / \mathrm{KSPS}$ yang memberikan kewenangan persetujuan pinjaman ke kantor cabang hanya sampai dengan nominal Rp 20 juta, masih dibawah pagu maksimal KUR Mikro sebesar Rp 25 juta.

Ketiga, memiliki anggota dalam jumlah yang relatif besar dengan proporsi karakter anggota yang memiliki usaha cukup signifikan. Pertimbangannya adalah, di satu sisi jumlah anggota yang relatif besar akan memudahkan $\mathrm{KSP} / \mathrm{KSPS}$ menghimpun dana sebagai sumber permodalan untuk membiayai KUR. Di sisi yang lain, proporsi yang signifikan dari anggota yang memiliki usaha memberi peluang bagi KSP/KSPS untuk menyalurkan KUR ke sektor yang produktif.

Keempat, memiliki strategi untuk meningkatkan ability to repay dari anggota yang mempunyai pinjaman. Sebagaimana telah dijelaskan sebelumnya, di beberapa KSP/KSPS yang dikunjungi, strategi ini pada intinya dibangun melalui kelompok untuk 
mengembangkan value chains dari kegiatan usaha kelompok. Di Keling Kumang, strategi ini terwujud melalui SHG (Self Help Group), sedangkan di Obor Mas terbangun melalui KS (Kelompok Solidaritas).

Di Obor Mas, KS terbentuk dari 20 50 anggota yang memiliki usaha. Obor Mas berperan sebagai pengelola dan aktif melakukan pembinaan dengan melakukan pertemuan secara rutin, paling tidak seminggu sekali. Seorang Pembina dari Obor Mas bertanggung jawab untuk menangani sampai dengan $25 \mathrm{KS}$. Dalam pertemuan, pembina dari Obor Mas memberikan pendidikan mengenai manajemen keuangan, khususnya dalam pengelolaan tabungan dan pinjaman. Pembina juga aktif memotivasi anggota KS untuk mengembangkan usahanya, salah satunya melalui penyediaan informasi pasar serta mendorong anggota yang memiliki usaha untuk berinteraksi. Misalnya, anggota yang memiliki usaha tempe disarankan membeli kedele dari anggota KS yang melakukan budidaya kedele, serta menjual tempenya di beberapa warung yang juga anggota KS.

Penting untuk dikemukakan bahwa KSP/ KSPS sendirian tidak akan optimal untuk mengembangkan value chains berbasis kelompok. Kerjasama, baik dengan dinas terkait (seperti Dinas Pertanian dan Dinas Perdagangan) maupun dengan pihak swasta, menjadi krusial untuk mengembangkan value chains yang berkelanjutan.

\section{Sumber Daya Manusia}

Sebagaimana telah dijelaskan sebelumnya, salah satu kunci sukses BRI menjadi roles model dalam program KUR terletak pada struktur SDM yang terbangun secara solid. BRI mengangkat account officers (mantri KUR) yang rata-rata berpendidikan sarjana (S1) dengan tugas khusus mengelola KUR. Mantri KUR berperan sebagai ujung tombak penyaluran, pemasaran dan pencarian nasabah potensial KUR. Setiap tahun, mereka diberi tanggung jawab menyalurkan KUR dengan kelipatan Rp 420 juta, dan mencari 22 orang nasabah KUR baru. Dengan struktur SDM yang solid, BRI mampu melakukan ekspansi KUR tanpa mendorong peningkatan kredit bermasalah (NPL). Fakta menunjukkan NPL BRI memang selalu jauh lebih rendah dibandingkan dengan batas toleransi sebesar $5 \%$.

Beberapa KSP/KSPS yang dikunjungi memiliki skenario untuk mengadopsi pola account officers seperti yang dikembangkan BRI. Perbedaanya dari pola account officers BRI adalah: Pertama, account officers yang diangkat di beberapa KSP/KSPS rata-rata berpendidikan SLTA. Karena itu, gaya komunikasi, perlakuan, dan pemahaman mengenai pengelolaan KUR mungkin akan berbeda dengan yang sudah berkembang dan menjadi patronnya BRI.

Kedua, dalam skenario yang dikembangkan beberapa KSP/KSPS, account officers memiliki tugas dan tanggung jawab yang relatif lebih berat dibandingkan dengan account officers BRI. Di beberapa KSP/KSPS, account officers tidak hanya fokus dalam pengelolaan KUR, tetapi juga memiliki tugas dan tanggung jawab mengelola pinjaman regular. Masalahanya, pinjaman regular KSP/ KSPS cenderung bersifat konsumtif. Hal ini terungkap paling tidak dari tiga kasus (Balota, Obor Mas, dan Pancur Kasih) dimana mereka mengaku sekitar $60 \%$ dari total pinjaman tersalur ke sektor konsumtif, seperti kredit kendaraan bermotor, perumahan, pendidikan, dan kesehatan (juga kematian). Sebagaimana telah dikemukakan sebelumnya, sifat, karakter, dan perlakuan dalam pengelolaan pinjaman (kredit) produktif cenderung berbeda dari pinjaman konsumtif. Proses pengembalian pinjaman produktif relatif lebih berisiko dibandingkan dengan pinjaman konsumtif karena tergantung dari keberhasilan usaha yang dikembangkan peminjam. Dibutuhkan account officers yang fokus menjalankan tugas dan tanggung jawabnya serta memiliki pemahaman yang baik mengenai dinamika usaha peminjam.

Ketiga, account officers KSP/KSPS memiliki tugas dan tanggung jawab yang tidak ringan dikaitkan dengan target penyaluran KUR. Misalnya, dengan target penyaluran Rp 50 milyar, Kospin Jasa berencana mendistribusikannya hanya ke 10 kantor cabang, dengan alokasi Rp 5 milyar per cabang. Setiap kantor cabang yang terpilih rata-rata memiliki 4 orang account officers. Ini berarti setiap account officer memiliki tanggung jawab menyalurkan KUR Rp 
1,250 milyar. Dengan asumsi, setiap nasabah mengoptimalkan pinjaman KUR sampai dengan Rp 25 juta, setiap account officers juga memiliki kewajiban mencari nasabah KUR sebanyak 50 orang.

Dengan target setiap account officer di Kospin Jasa mampu menyalurkan Rp 1,250 milyar untuk paling tidak 50 orang nasabah, beban kerja mereka jelas lebih berat daripada rekannya di BRI. Beban account officer di Kospin Jasa semakin bertambah berat karena mereka juga berkewajiban mengelola pinjaman regular. Isu mengenai beban kerja account officers ini penting mendapat perhatian untuk menjaga agar proses penyaluran KUR tepat sasaran, tidak bermasalah pada saat pengembaliannya, dan berdampak secara positif terhadap pemberdayaan UMKM.

\section{Infrastruktur IT}

Kemampuan KSP/KSPS dalam membangun, mengembangkan, dan mengelola infrastruktur IT (information technology) menjadi syarat penting agar mereka bisa berpartisipasi sebagai penyalur KUR, paling tidak karena dua alasan. Pertama, KSP/KSPS harus memiliki sistem IT yang terkoneksi secara host-to-host dengan SIKP. Ini karena KSP/ KSPS yang ikut serta dalam program KUR berkewajiban mengunggah data nasabah, seperti identitas nasabah, jumlah dan tenor pinjaman, sektor usaha serta peruntukan pinjaman (Kredit Modal Kerja/KMK atau Kredit Investasi/KI), ke SIKP. Data nasabah yang diunggah menjadi basis yang bisa digunakan pemerintah untuk membayar subsidi. Jika KSP/KSPS tidak memiliki jaringan IT untuk mengunggah data nasabah ke SIKP, pemerintah tidak bisa membayar subsidi ke KSP/KSPS.

Kedua, KSP/KSPS harus memiliki jaringan IT yang terkoneksi secara host-tohost dengan Sistem Informasi Debitur (SID) yang dikelola OJK dan Bank Indonesia (BI). Koneksi ke SID diperlukan untuk memastikan bahwa calon nasabah memiliki catatan sejarah peminjaman yang baik. SID merupakan tahap awal dalam proses seleksi untuk menentukan bisa-tidaknya seseorang menerima kredit, termasuk KUR.
Pentingnya peran infrastruktur IT dalam mendukung proses penyaluran KUR membuat pemerintah melakukan pengujian secara hati-hati terhadap kemampuan jaringan IT yang dibangun dan dikembangkan calon lembaga keuangan penyalur, termasuk KSP/ KSPS. Tidak mengherankan jika Kospin Jasa misalnya, meskipun KSP ini sudah mendapatkan izin untuk menyalurkan KUR sejak kuartal pertama tahun 2017 , tetapi hingga memasuki paruh kedua tahun 2017 belum dapat menyalurkan KUR. Kementerian Keuangan masih terus melakukan proses uji coba terhadap stabilitas dan kemapanan sistem IT yang dibangun dan dikembangkan KSP ini.

Sebagaimana ditunjukkan Tabel 6, terdapat $2 \mathrm{KSP} / \mathrm{KSPS}$ yang sistem IT-nya bisa dikembangkan agar terkoneksi dengan SIKP dan SID, yaitu Kospin Jasa dan Obor Mas. Pada kasus Kospin Jasa, sebagai bagian dari strategi untuk mendukung kegiatan bisnisnya, KSP ini sudah mulai berinvestasi untuk membangun sistem IT sejak tahun 2008. Karena itu, Kospin Jasa memiliki sistem IT yang relatif maju. Seluruh kantor cabangnya sudah terkoneksi secara online. KSP ini juga sudah mampu memberikan layanan jasa keuangan digital. Anggota KSP dapat bertransaksi via aplikasi mobile phone dan bisa melakukan transaksi serta penarikan tunai di jaringan Automatic Teller Machine (ATM) Bersama, Alto, Prima dan Visa. Dengan demikian, anggota Kospin Jasa masih tetap bisa melakukan transaksi atau penarikan tunai melalui ATM jika mereka sedang berada di luar wilayah kerja Kospin Jasa, atau bahkan ketika di luar negeri.

KSP Obor Mas juga telah mengembangkan sistem IT yang membuat seluruh kantor cabang bisa terkoneksi secara online. Sayangnya, basis data anggota di KSP ini belum terdigitalisasi seluruhnya. Oleh karena itu, Kemenkeu meminta KSP ini melengkapi digitalisasi anggota secara bertahap, sehingga data tersebut bisa diunggah dan terkoneksi dengan SIKP dan SID.

\section{KESIMPULAN}

Pelibatan koperasi (KSP/KSPS) sebagai penyalur KUR membuka peluang sekaligus tantangan pada proses perbaikan kinerja 
dan tata pelaksanaan KUR. Sebagai sebuah lembaga ekonomi yang cukup dekat dan sangat memahami permasalahan serta kebutuhan UMKM, pelibatan koperasi membuka peluang terjadinya peningkatan outreach KUR. Pelibatan koperasi juga membuka peluang terhadap peningkatan porsi KUR yang tersalur ke sektor produktif dan lebih mampu menjangkau provinsi di luar Pulau Jawa.

Namun demikian, upaya untuk melibatkan koperasi sebagai penyalur KUR menghadapi beberapa tantangan. Sebagaimana telah dijelaskan pada bagian sebelumnya, salah satu faktor yang membuat koperasi berpikir ulang untuk berpartisipasi dalam program KUR adalah keterlambatan dalam proses pembayaran subsidi. Karena itu, pemerintah idealnya melakukan beberapa pembenahan untuk menyederhanakan kompleksitas dan meningkatkan efektivitas proses pembayaran subsidi kepada lembaga keuangan penyalur KUR.

Selain itu, KUR didesain sebagai sebuah produk perbankan. Dengan demikian, KUR terikat dengan aturan-aturan microprudentials yang sangat rigid dan kompleks. Koperasi membutuhkan periode adaptasi dengan aturan-aturan KUR. Secara internal koperasi juga seringkali dihadapkan dengan beragam permasalahan yang membawa dampak negatif terhadap penurunan kemampuan mereka dalam melakukan proses simpan-pinjam.

Agar bisa mendapatkan manfaat yang optimal, koperasi yang terlibat sebagai penyalur KUR perlu memiliki kompetensi dan kapasitas secara prima. Mereka harus mampu memenuhi persyaratan, paling tidak di empat bidang sebagai berikut: Pertama, memiliki aset bisnis dan struktur permodalan yang kuat. Kedua, mampu mengembangkan tata kelola dan memiliki sejarah serta pengalaman dalam pengelolaan dan penyaluran kredit (pinjaman) mikro yang sifatnya produktif. Ketiga, memiliki kemampuan untuk membangun kualitas SDM yang profesional dan memahami seluk beluk kredit mikro. Keempat, mampu mengembangkan infrastruktur IT yang bisa memfasilitasi mereka untuk beradaptasi dengan dinamika simpan-pinjam.

\section{DAFTAR PUSTAKA}

Adam, L. (2009). The Economic Role of InterFirm Networks in the Development of SMEs, Study of Symbiosis in the Indonesian Garment Industry. Lambert Academic Publishing.

Adam, L. (2010). The Role of SMEs in the Indonesia Industrialization. Economic and Finance in Indonesia, 45 (1), 15--30.

Adam, L. (2011). Hubungan Diantara Pertumbuhan Ekonomi dan Penurunan Kemiskinan. Jurnal Ekonomi, 16 (1), 79-93.

Adam, L. (2017). Evolusi Program Kredit Mikro. Dalam Nugroho, A. (ed.). Komersialisasi Kredit Usaha Rakyat untuk Pemberdayaan UMKM di Indonesia. LIPI Press, 20-35.

Adam, L. dan Lestari, E. (2017). Indonesia's Guaranteed Microfinance Program (KUR): Lesson from the First Stage of Implementation. Journal of Southeast Asian Economiest. 34 (2), 322-344.

Assa, J.B., H. Tampajara, S. Endi. (2017). Segala Permulaan itu Sulit. Pohon Cahaya.

Badan Pusat Statistik. (2014). Survey Industri Mikro dan Kecil (VIMK) Tahun 2014.

Badan Pusat Statistik. (2016). Survey Sosial Ekonomi Nasional (Susenas) Tahun 2016.

Berry, A., Rodriguez, E., dan Sandee, H. (2001). Small and Medium Enterprise Dynamics in Indonesia. Bulletin of Indonesian Economic Studies, 37 (3), 363-84.

Djunaid, H.A.Z.A. dan Djunaid, H.A. (2002). Berpikir Besar dalam Koperasi. Perintis Jasa.

Firdausy, C., M. (2005). Roles, Problems and Policies of the Indonesian Small and Medium Enterprises in Globalization. Dalam Tisdell, C. (ed). Globalization and World Economic Policies: Effects and Policies Responses of Nations and Their Grouping, New Delhi Serial Publication, 249-72.

Gustifa, R. (2013). Faktor-Faktor yang Mempengaruhi Kredit Macet pada Koperasi Simpan Pinjam di Kota Padang. Manajemen, 1 (1), 1-21. 
Hadiwinata, B. S. (2003). The Politics of NGOs in Indonesia: Developing Democracy and Managing a Movement. Routledge Courzon.

Hamada, M. (2010). Commercialization of Microfinance in Indonesia: Shortage of Funds and the Linkage Program. Developing Economies, 48 (1), 156-76.

Harvie, C., Narjoko, D. dan Oum, S. (2013). Small and Medium Enterprises' Acces to Finance: Evidence from Selected Asian Economies. ERIA Discussion Paper Series No. 23, October 2013.

Hill, H. (2002). Old Policies Challanges for A New Administration: SMEs in Indonesia. Dalam Harvie, C. dan Lee, B.C. (eds). The Role of SMEs in National Economies in East Asia, , Edward Elgar, 158-80.

Johnson, D. dan Murdoch, J. (2007) Microcredit vs. Micro Savings: Evidence fromm Indonesia. Survey Design and Implementation, Ford Foundation and Gates Foundation.

International Finance Corporation. (2016). UKM yang Dimiliki Wanita di Indonesia Kesempatan Emas Untuk Institusi Keuangan Lokal. Diambil dari http://www.worldbank. org/curated/en/737221477568795492/ UKM-yang-dimiliki-wanita-di-Indonesiakesempatan-emas-untuk-institusi-keuanganlokal

Kementerian Koordinator Bidang Ekonomi. (2014). Buku Perkembangan Kredit UMKM dan Pelaksanaan Kredit Usaha Rakyat (KUR)

Kementerian Koordinator Bidang Ekonomi. (2016). Buku Perkembangan Kredit UMKM dan Pelaksanaan Kredit Usaha Rakyat (KUR)

Kementerian Koordinator Bidang Ekonomi. (2017). Buku Kumpulan Peraturan Kredit Usaha Rakyat (KUR)

Kementerian Koperasi dan UKM. (2013). Perkembangan Data Usaha Mikro, Kecil, dan Menengah (UMKM) dan Usaha Besar (UB) Tahun 2013. http://www.depkop.go.id/ berita-informasi/data-informasi/data-umkm/

Kementerian Koperasi dan UKM. (2014). Keragaan Koperasi Simpan Pinjam Tahun 2014
McLeod, R. (1994). Indonesia Assesment 1994: Finance as a Key Sector in Indonesia's Development. Institute of Southeast Asian Studies.

Musa, A. dan Priatna. (1998). The Policy Reform for Capital of SME in Indonesia: Impact Analysis of Financial Crisis. Asia Foundation.

Noordiansyah, A. (2010). Analisis Kredit Bermasalah pada Koperasi Simpan Pinjam (KSP) Harapan Mulya Kudus. Undergraduate Thesis. Semarang: Universitas Negeri Semarang.

Nugroho, A. E. (2011). Microfinance Development in Indonesia Market Segmentation, Social Capital and Welfare Outreach to the Poor in Rural Java. Lambert Academic Publishing.

P2E-LIPI. (2014). KUR di Era Otonomi Daerah: Membangun Sinergi antara Kelembagaan Pasar, Pemerintah Daerah dan Komunitas dalam Pengelolaan Kredit Program untuk Pemberdayaan UMKM. LIPI Press.

Sato, Y. (2000). Linkage Formation by Small Firms: The Case of A Rural Cluster in Indonesia". Bulletin of Indonesian Economic Studies, 36 (1), 137-66.

Sarwoko, E. (2009). Analisis Peranan Koperasi Simpan Pinjam/Unit Simpan Pinjam dalam Pengembangan UMKM di Kabupaten Malang. Modernisasi. 5 (3), 172-188.

Siebel, H. D. (2005). The Microbanking Division of Bank Rakyat Indonesia: A Flagship of Rural Microfinance in Asia". Development Research Center Working Paper No. 2.

Sihombing, M.I.S. (2016). Alternatif Penyelesaian Sengketa Kredit Macet dengan cara Negosiasi pada Koperasi Simpan Jaya Niaga Kabupaten Semarang, Undergraduate Thesis Fakultas Hukum dan Komunikasi Universitas Soegijapranata Semarang.

Takashi, K., Higashikata, T., dan Tsukada, K. (2010). The Short-Term Poverty Impact of Small-Scale, Collateral-Free Microcredit in Indonesia: A Matching Estimator Approach. Developing Economies, 48 (1), 128-55.

Thee, K. W. (2003). Kebijakan Pembangunan UKM: Beberapa Pemikiran. Discussion Paper, P2E-LIPI. 
Thee, K.W. (2006). Policies for Private Sector Development". ADB Institute Discussion Paper No. 46.

TNP2K. (2014). An Analysis on the Impact of the Increasing Number of Participating Banks that Provide the KUR Mikro Loans.

TNP2K. (2015a). Program Kredit Usaha Rakyat (KUR) sebagai Alat Pendorong Pengembangan UMKM di Indonesia.

TNP2K. (2015b). Reforming Policies for Small and Medium Sized Enterprises in Indonesia. van Diermen, P. (1997). Small Business in Indonesia. Aldershot. Ashgate.

Vos, E., Yeh, A.J.Y., Carter, S., dan Tagg, S. (2007). The Happy Story of Small Business Financing. Journal of Banking \& Finance, 31 (9), 2648-72.

Yamamoto, I. (2001). The Dynamism of Small and Medium Enterprises and Inter-Firm Linkage in Indonesia. Nippon 5 (1), 1-23. 
46 | Jurnal Ekonomi dan Pembangunan Vol26, No. 1, 2018 